\title{
The Distribution and Consequences of Sexual Misconduct Perpetrated by Peacekeepers in Haiti: An Exploratory Cross-Sectional Analysis
}

\author{
Luissa Vahedi ${ }^{1, *(D)}$, Heather Stuart ${ }^{1}$, Stéphanie Etienne ${ }^{2}$, Sabine Lee ${ }^{3}$ and Susan A Bartels ${ }^{1,4}$ \\ 1 Department of Public Health Sciences, Queen's University, Kingston, ON K7L 3N6, Canada; \\ heather.stuart@queensu.ca (H.S.); susanabartels@gmail.com (S.A.B.) \\ 2 Komisyon Fanm Viktim pou Viktim (FOFAVIV), Port au Prince, Haiti; estephie2011@yahoo.fr \\ Department of History, University of Birmingham, Birmingham B15 2TT, UK; s.lee@bham.ac.uk \\ 4 Department of Emergency Medicine, Queen's University, Kingston, ON K7L 4V7, Canada \\ * Correspondence: 16LV6@queensu.ca
}

check for

updates

Citation: Vahedi, Luissa, Heather Stuart, Stéphanie Etienne, Sabine Lee, and Susan A Bartels. 2021. The Distribution and Consequences of Sexual Misconduct Perpetrated by Peacekeepers in Haiti: An Exploratory Cross-Sectional Analysis. Social Sciences 10: 270. https:// doi.org/10.3390/socsci10070270

Academic Editor: Sandra Walklate

Received: 16 May 2021

Accepted: 8 July 2021

Published: 15 July 2021

Publisher's Note: MDPI stays neutral with regard to jurisdictional claims in published maps and institutional affiliations.

Copyright: (c) 2021 by the authors. Licensee MDPI, Basel, Switzerland. This article is an open access article distributed under the terms and conditions of the Creative Commons Attribution (CC BY) license (https:/ / creativecommons.org/licenses/by/ $4.0 /)$.

\begin{abstract}
During the United Nations Stabilization Mission in Haiti (MINUSTAH), reports of sexual abuse and exploitation and children fathered by peacekeepers were brought forward to the UN. In 2017, a cross-sectional mixed-methods survey was administered by Haitian research assistants using SenseMaker ${ }^{\circledR}$ (Cognitive Edge, Singapore), a rapid data collection tool that allows participants to share a narrative on a topic of interest. In total, 2541 self-interpreted narratives in relation to the experiences of Haitian women and girls vis-à-vis peacekeepers were collected from a convenience sample of Haitian males and females across Haiti. This exploratory secondary data analysis analyzes whether narratives about sexual misconduct perpetrated by MINUSTAH peacekeepers were associated with rural, semi-urban, or urban locations and investigates the relationship between sharing narratives about sexual misconduct and the desire to engage with the UN/MINUSTAH. After adjustment, narratives addressing sexual misconduct were more likely to be shared in rural locations, compared to urban locations $\left(\mathrm{RR}_{\text {rural }}: 1.19 ; 95 \% \mathrm{CI}: 1.03,1.38\right)$. Personal experiences of sexual misconduct were more likely $\left(\mathrm{RR}_{\mathrm{sex}}: 4.52 ; 95 \% \mathrm{CI}: 3.34,6.12\right)$ to be associated with rejection of the UN/MINUSTAH, compared to personal narratives of positive/neutral experiences. This research is an empirical steppingstone to understanding the distribution and consequences of peacekeeper-perpetrated sexual abuse and exploitation in Haiti.
\end{abstract}

Keywords: Haiti; United Nations; peacekeeping; sexual violence; social epidemiology; sexual abuse; exploitation reporting

\section{Introduction and Literature Review}

Over the years, Haiti has experienced civil and political unrest including natural disasters, coups, political leader assassinations, and organized crime (Baranyi 2011). Through Resolution 1542, the United Nations Security Council (UNSC) sanctioned the United Nations Stabilization Mission in Haiti (MINUSTAH) in 2004. Ending officially in 2017, MINUSTAH was the longest peacekeeping operation (PO) in Haiti (Diehl 2008). The mission was authorized to include 6700 military personnel, 1622 police, 550 international civilian personnel, and 1000 local civilian staff (Heine and Thompson 2011). MINUSTAH was initially mandated to protect civilians from the threat of armed gangs and intrastate conflict (dos Santos Parra 2019). However, in light of earthquake-related losses in 2010 and the absence of legitimate governance structures, the mission's scope and number of personnel expanded to also include humanitarian relief, support of democratic elections, and the protection of human rights (Rivera 2018; Heine and Thompson 2011). Following the January 2010 earthquake that resulted in approximately 300,000 deaths and the internal displacement of over one million Haitians (Government of the Republic of Haiti 2010), the 
UNSC increased deployment to a peak of 13,000 military and police peacekeepers (United Nations Security Council, 2010b). The earthquake's effects, including internal displacement, substantial morbidity and mortality, colossal material damage, and foreign humanitarian intervention at the cost of displacing national actors and feminist organizations (Romulus 2016), magnified vulnerability to multilevel abuses of power, including the perpetuation of SEA. Concerns have been raised about sexual exploitation and abuse (SEA) perpetrated by MINUSTAH peacekeepers, including resultant pregnancies and peacekeeper-fathered children, pre- and post-earthquake (Vahedi et al. 2019, 2020; Simić and OBrien 2014).

Peacekeeper-perpetrated sexual misconduct first gained attention during the UN Transitional Authority in Cambodia (UNTAC) in 1992-1993, when UN peacekeepers magnified the existing sex work industry (Alexandra 2011). Since then, SEA by peacekeepers has been reported in a number of PO including those in Haiti, Libera, Central Africa Republic and the Democratic Republic of Congo (United Nations Secretariat 2005; Catherine et al. 2009). To address SEA by its personnel, in 2003 the UN introduced the Zero Tolerance Policy, which recognized and defined two forms of sexual violence within peacekeeping contexts: sexual exploitation and sexual abuse (United Nations Secretariat 2003). Sexual exploitation is defined as the abuse of power to enact sexual violence and sexual abuse is the use of coercion or force to enact intrusions of a sexual nature (United Nations Secretariat 2003). Generally, the UN maintains that sexual relations between peacekeepers and beneficiaries of assistance are exploitative or abusive because they are based on unequal power dynamics. UN peacekeepers are discouraged from engaging sexually with beneficiaries of assistance; sexual relations involving peacekeepers, including transactional sex, violates codes of conduct and constitutes sexual misconduct. SEA is also a category one offense- the most serious type of misconduct (Jennings 2008). From 2007 to March of 2021, 119 allegations of SEA against MINUSTAH peacekeepers have been formally reported to the UN (United Nations 2020a). Moreover, within the same time period, 36 SEA-related paternity claims have involved MINUSTAH peacekeeping personnel, with eight of those having been positively confirmed (United Nations 2020b).

In this paper we use the term sexual misconduct to broadly include all sexual interactions between MINUSTAH peacekeepers and beneficiaries of assistance. While scholars have contested the UN's framing that all sexual interactions with peacekeepers are inherently abusive and exploitative and have illustrated the agency of some women vis-à-vis transactional sex (Simić 2009; Vahedi et al. 2019, 2021), the purpose of the present work is to quantitatively determine the distribution and consequences of sexual interactions with peacekeepers, without further classifying the sexual relations.

An emerging body of literature has sought to quantitatively examine SEA. For example, a 2012 cross-sectional study in Liberia analyzed transactional sex between Liberian women aged 18 to 30 and foreign military personnel deployed to the United Nations Mission in Liberia (UNMIL) (Beber et al. 2017). In this sample, 56\% of Liberian women had engaged in transactional sex, and $44 \%$ of these did so with peacekeepers. For every additional 1000 peacekeepers deployed, the probability of a Liberian woman engaging in her first transactional sexual encounter increased by $3 \%$.

Using data made publicly available by the UN, Nordås and Rustad (2013) examined the variation in reported SEA allegations across different PO between 1999 and 2010. Risk factors positively associated with reported SEA included mission-level factors (type of mandate-i.e., humanitarian assistance and focus on gender equality, high levels of violence during conflict, and large mission size) as well as host-country factors (high level of sexual violence preceding conflict, low GDP per capita, and absence of spousal rape law). Similarity, Moncrief (2017) analyzed PO data from 2007 to 2014 from a variety of publicly available sources and concluded that increasing mission size was significantly associated with greater SEA allegations. Increasing host-country GDP per capita was significantly related to reduced SEA allegations (Moncrief 2017). In addition, the disciplinary erosion of a contingent, measured by contingents with reports of misconduct unrelated to SEA, was found to be positively associated with SEA allegations. 
Using UN PO data (2006-2011), Karim and Beardsley (2013) examined the effectiveness of deploying female peacekeepers with respect to reducing SEA allegations. Results indicated negative correlations between the deployment of female peacekeepers and (i) the number of deaths during PO and (ii) GDP per capita of the host county, suggesting that female peacekeepers were more likely to be deployed to safer areas that are more economically secure. Karim and Beardsley (2016) also investigated the effectiveness of female peacekeepers and gender equality on the number of SEA allegations between 2009 and 2013. The authors demonstrated that an increased proportion of female peacekeepers was negatively correlated with SEA allegations. Gender equality measures of Troop Contributing Country (TCC) (measured by primary school and labour force gender ratios) were also negatively correlated with SEA allegations. Lastly, Karim (2017) assessed Liberian perceptions of female peacekeepers using microdata, concluding that civilian contact with female peacekeepers was positively associated with favourable perceptions of them. However, there were no significant associations with perceptions of improved security with respect to SEA, and female peacekeepers faced barriers accessing local civilians, especially women and girls.

Building on the existing body of scholarship concerning the quantitative analysis of SEA, this paper presents a secondary data analysis of a novel dataset collected in Haiti. In 2017, a large sample of microlevel experiences/narratives related to MINUSTAH were collected from Haitians living in proximity to MINUSTAH bases across rural and urban locations as well as the northern, central, and southern regions using SenseMaker.

SenseMaker is a mixed methods data collection tool that allows participants to share and interpret narratives related to a phenomenon of interest without probing or direct questions related to the phenomenon. Although the present analysis relies on purposeful and convenience sampling of Haitian experiences and perceptions vis-à-vis MINUSTAH, it offers valuable insights regarding where narratives of SEA were openly shared and how such narratives impact perceptions related to the legitimacy of peacekeeping in Haiti.

This secondary analysis (i) explores whether sexual misconduct narratives are associated with geographical locations (rural, semi-urban, urban) and (ii) explores whether sharing a narrative about sexual misconduct is associated with perceptions of rejecting UNrelated peacekeeping. To our knowledge, the present analysis is the first use of regression modeling to analyze SenseMaker data on peacekeeper-perpetrated SEA. Accordingly, below we describe the proposed mechanisms and hypotheses that correspond to our research objectives.

\subsection{Mechanism and Hypothesis for Objective 1: Geographic Distribution of Narratives That Address Sexual Misconduct}

Peacekeeping economies have been well studied (Aning and Edu-Afful 2013; Henry 2015; Higate and Henry 2004; Jennings and Nikolić-Ristanović 2009; Jennings and Bøås 2015) and refer to "economic activity that either would not occur or would occur at a much lower scale and rate of pay, without the international presence, of which a UN peacekeeping mission is a central component" (Jennings 2014). In Haiti, socioeconomic vulnerability and ubiquitous gender inequality result in a range of gendered survival strategies that disproportionately affect women and girls, such as trading sex for money, food, or security (i.e., transactional sex) (Fawzi et al. 2005). In this context, the influx of foreign, well-paid, and predominantly male peacekeepers magnifies the gendered economies of women's labour: sex work, transactional sex, and domestic work. Peacekeeping economies that preferentially employ women and girls implicate work in unregulated, informal, precarious, and/or illicit sectors that have no legal or social protection. The willful or coerced participation in peacekeeping economies increases risk for experiencing SEA (Jennings and Nikolić-Ristanović 2009).

We considered the relationship between peacekeeping bases located in urban, semiurban, and rural regions and narratives about sexual misconduct. Women and girls in rural Haiti face greater socioeconomic disparities compared to their urban or semi-urban counterparts, on account of fewer opportunities for education, employment, reduced access 
to health and social services, greater reliance on remittances from emigrated relatives, and increased employment in the informal sector (Verner 2008; Orozco 2006; Edmond et al. 2007; Padgett and Warnecke 2011; Fawzi et al. 2005). We propose that rural, urban, and semi-urban geographical locations are associated with differential participation in the gendered peacekeeping economies of transactional sex, domestic work, and sex work, thereby resulting in a greater sharing of narratives about SEA.

Given that the authors performed secondary data analysis, no data pertaining to participation in peacekeeping economies was available. Instead, we analyzed the association between geographical location and whether a narrative mentioned sexual misconduct perpetrated by peacekeepers. Thus, we hypothesize that participation in peacekeeping economies will be more pronounced, and sharing of SEA narratives will be higher in rural locations compared to urban and semi-urban locations. One limitation to this mechanism (discussed in greater detail in the discussion) is that rural communities may be more socially cohesive; SEA, transactional sex, and foreign peacekeepers may be more novel in rural communities, and subsequently, narratives about SEA being more frequently shared in rural locations.

\subsection{Mechanism and Hypothesis for Objective 2: Exposure to Sexual Misconduct and Future Engagement with the UN}

Contextual information from civilians is often essential for the success of PO, and yet it can be challenging for peacekeepers to gather this information when they are not cohesively integrated into the host community. The cooperation and engagement of local civilians has been shown to depend on the degree to which local communities positively perceive peacekeepers (Gordon and Young 2017). Local civilians may not have access to reliable information about peacekeepers (Talentino 2007) and instead may rely on personal, vicarious, and community-level experiences regarding peacekeepers' day-to-day activities. In fact, civilian knowledge of SEA has been shown to negatively affect perceptions of peacekeepers and the UN, thereby reducing cooperation and engagement with PO (Morris 2010; Gordon and Young 2017; dos Santos Parra 2019).

We propose that the relationship between exposure to peacekeeper misconduct is mediated by perceptions of peacekeepers, which in turn affects the desire to engage with the UN and MINUSTAH in the future. Given that the authors performed secondary data analysis, no data pertaining to perceptions of peacekeepers was available. Instead, we analyzed the association between the sharing of narratives about misconduct and whether the events described in the narrative resulted in the participant accepting or rejecting the UN/MINUSTAH, under the theoretical framework of perception formation. Thus, we hypothesize that narratives addressing sexual misconduct by MINUSTAH peacekeepers will be associated with rejecting the UN/MINUSTAH, compared to narratives that did not address sexual misconduct by peacekeepers.

\subsection{Contribution of Research}

This research provides a contextualized understanding of SEA in Haiti. Based on community perceptions and narratives (as opposed to formal UN allegations), the analysis allows a grounded understanding of personal, vicarious, and community-level exposure to SEA in urban, semi-urban and rural regions, while also highlighting how these experiences impact Haitians' willingness to engage with the UN. The results have implications for how/where the UN focuses its SEA prevention and response interventions and resources, in addition to providing further evidence regarding how perceptions of SEA impact host community cooperation and engagement with the UN and its multilateral organizations. Given that SEA is widely under-reported in communities that host PO, researchers aiming to ascertain count data of SEA experiences are limited by allegations that are formally reported. Our dataset includes narratives and experiences of SEA that emerge unprompted from Haitians, thereby offering a more complete snapshot of sexual misconduct perpetrated by MINUSTAH peacekeepers. 


\section{Materials and Methods}

In partnership with Haitian community organizations Komisyon Fanm Viktim pou Viktim (KOFAVIV), Bureau des Avocates Internationaux (BAI), and Enstiti Travay Sosyal ak Syans Sosyal (ETS), a cross-sectional survey that collected self-interpreted narratives from Haitians in proximity to peacekeeping bases was administered in 2017. The methods presented below have also been described in other publications (Lee and Bartels 2020; Vahedi et al. 2021).

\subsection{Survey Implementation and Participants}

The survey was administered in Kreyol using the SenseMaker (Cognitive Edge, Sinagpore) application on the iPad Mini 4 s between June and August of 2017. SAB and SL facilitated a four-day research assistant training detailing the research protocol, SenseMaker, ethics, iPad use, data upload, management of adverse events, service referral, and roleplay activities for survey delivery. The research assistants represented two community partner organizations from Haiti: ETS and KOFAVIV. ETS supplied 10 research assistants (six female and four male) who were undergraduate students studying social work; KOFAVIV supplied 2 female research assistants who had experience volunteering and working with survivors of sexual-gender-based violence. Female research assistants were assigned to primarily interview female participants and male research assistants were assigned to primarily interview male participants.

The Haitian research assistants recruited a convenience sample of participants in cities, towns, and villages within a $30 \mathrm{~km}$ radius of the 10 selected MINUSTAH bases (Cité Soleil, Charlie Log Base, Tabarre, Léogâne, Cap Haiitien, Saint Marc, Gonaïves, More Casse, Fort Liberté, Hinche, and Port Salut). When the $30 \mathrm{~km}$ radiuses for two bases overlapped, the research assistants alternated between the two bases. Accordingly, survey collection was grouped for Charlie Log Base and Tabbare, Saint Marc and Gonaïves, Morne Casse and Fort Liberté. To purposefully select MINUSTAH bases, we used a combination of community partner knowledge, published peacekeeping data, geographical location (north, south, central plateau, metropolitan areas), base staffing characteristics, and dates of operation.

At each location, the research assistants approached prospective participants over the age of 11 from community settings including, markets, post offices, commercial settings, and bus stops. It was considered important to include adolescents because anecdotal evidence and SEA reports suggested that young girls are also affected by SEA. A variety of participant subgroups were recruited through convenience sampling to capture a diverse sample of narratives from varying perspectives: family members and friends of individuals who had interacted with MINUSTAH personnel, individuals who had interacted with MINUSTAH personnel, in addition to other community members and stakeholders.

\subsection{Instruments and Measures}

Data were collected using SenseMaker, a narrative-based mixed-methods data collection tool and research methodology (Cognitive Edge 2010). After collecting short narratives expressed verbally by the participant, SenseMaker requires participants to share their related feelings, attitudes, and perspectives by responding to a series of analytical questions (Girl Hub 2014). The narratives shared were short expressions of an experience or story and were on average approximately $90 \mathrm{~s}$ in length.

We used three prompting questions to elicit narratives and experiences from a variety of community members about how women and girls interact with MINUSTAH peacekeepers. However, the survey did not include direct questions about SEA, allowing stories about sexual interactions to emerge naturally from the broader landscape of experiences related to living in proximity to MINUSTAH bases (there was no prompting by the research assistants). Accordingly, participants could share any story in relation to the three included prompts.

After recording a narrative, participants self-interpreted the shared experiences by plotting their perspectives spatially using dichotomous sliders (dyads) or between three 
possible options (triads) (Figures A1 and A2 in Appendix C). SenseMaker then assigned quantitative values to the plotted self-interpretations. Participants also answered multiple choice questions pertaining to demographic and narrative characteristics.

Haitian community partners from KOFAVIV, ETS, and BAI contributed to the survey development. The survey was originally drafted in English, then translated to Kreyol and independently back translated to English. Translation discrepancies were resolved by agreement between the two translators. In March of 2017, the third, fourth, and fifth authors pilot tested the survey in Haiti among 54 participants who provided feedback to refine the instrument. To support qualitative analysis, the audio-recorded narratives were transcribed and translated from Kreyol to English. The survey is presented in Appendix A.

\subsubsection{Geographical Distribution of Narratives about Sexual Misconduct Model}

The exposure variable was the geographical location where the narrative was captured, classified as rural, urban, and semi-urban. The designations of urban, rural, and semi-urban categories were proposed by the Haitian community partners and cross-referenced with the Demographics and Health Survey (DHS). The urban category (referent) was comprised of Cité Soleil, Charlie Log Base and Tabarre, all of which form metropolitan Port-au Prince (this is in line with the DHS); Léogâne and Cap Haïtien were grouped as semi-urban; the rural category was comprised from St. Marc and Gonaïves, Morne Casse and Fort Liberté, Hinche, and Port Salut.

For the outcome variable, each narrative was coded into a binary measure according to whether the narrative mentioned or described sexual misconduct. Decisions pertaining to whether narratives mentioned sexual misconduct were made by the Haitian research assistants immediately after data collection and later verified by the first author. Similar to the UN's Zero Tolerance Policy (United Nations Secretariat 2003), narratives that mentioned or described any sexual interactions with peacekeepers were identified as being about sexual misconduct. Namely, SEA, long-term sexual relationships perceived as consensual, children fathered by peacekeepers, sexual assault, and statutory sexual assault were all classified as sexual misconduct (Refer to Appendix D for a comprehensive description of the sexual misconduct category).

While the UN's stance on SEA has been critiqued (Vahedi et al. 2019; Simić 2009), we employ this criteria as a standardized means of identifying experiences of sexual interactions with MINUSTAH peacekeepers within our sample of narratives. First-hand experiences of sexual interactions with peacekeepers as well as narratives about the experiences of family/friends, and experiences of other community members were included in the sexual misconduct category. In some cases, narratives addressed multiple forms of SEA such as SEA perpetrated against Haitian women/girls and Haitian men/boys. Despite the three prompting questions priming participants to share narratives about women and girls in their community, some narratives exclusively discussed SEA perpetrated against men and boys. When sexual interactions between MINUSTAH peacekeepers and Haitian men and boys were mentioned in a narrative, such narratives were also coded as sexual misconduct.

\subsubsection{Consequences of Exposure to Sexual Misconduct Model}

The primary exposure variable for the second regression model was the subject matter of the narratives. Narratives were grouped into three exposure groups, based on the predominant subject-matter and emotional tone: (i) positive and neutral narratives of the UN/MINUSTAH that did not address wrongdoings perpetrated by peacekeepers (referent group - examples include employment offered by peacekeepers, safety improvement, public service, humanitarian assistance, friendships); (ii) narratives addressing sexual misconduct perpetrated by MINUSTAH peacekeepers; or (iii) narratives about other UN wrongdoings and negative perceptions of the UN unrelated to sexual misconduct (examples include: cholera outbreak, use of tear gas, violence against civilians, water supply 
contamination, littering, kidnapping, goat stealing, motor-vehicle collisions, improper waste disposal) (Refer to Appendix D for examples of narratives within each category).

The outcome was derived from the dyad question asking about willingness to engage with the UN: "Events in the story led the community to have an overwhelming desire to engage with the UN or MINUSTAH (0) or absolute rejection of the UN or MINUSTAH (100)". The dyad's quantitative scale across the $x$-axis ranged from 0 to 100 . The dyad scale was binned into 12 equal intervals from 0 to 100 in the direction of "Absolute rejection of the UN or MINUSTAH", creating a histogram with the frequency of responses on the $y$-axis, as depicted in the supplementary document.

The frequency of responses fell within three distinct response patterns across increasing tertile increments of the dyad scale. The bottom tertile of the dyad scale ranging from 0 up to 33.3 was in the direction of "Overwhelming desire to engage with the UN and MINUSTAH"; the middle tertile of the dyad scale ranging from 33.3 up to 66.7 was in the middle of the two response options; the highest tertile of the dyad scale ranging from 66.7 to 100 was in the direction of "Absolute rejection of the UN and MINUSTAH". Therefore, the outcome was included in the regression model as a binary variable. Perceptions ranging from 66.67 to 100 on the dyad scale expressed a desire to reject the UN and MINUSTAH (coded as 1), whereas perceptions ranging from 0 up to (but not including) 66.67 expressed a desire to engage with the UN (coded as 0 ). The distribution of responses for the dyad question used to form the outcome is presented in Appendix $C$.

\section{Covariates}

Five categorical variables pertaining to participant demographics (gender, relationship status, education, income, age) and three categorical variables pertaining to the narrative characteristics (who was the narrative about, emotional tone, and location) were considered as potential covariates, confounders, or effect modifiers. Given the novel use of SenseMaker to gather Haitian perceptions and experiences of SEA, we relied on a data driven approach to identify potential confounders. To identify potential confounders at the bivariate level, we conducted chi-squared tests between the covariates and the exposure and outcome variables in each model using a 0.05 level of significance. During model building, parameter estimates corresponding to the exposure variable were compared between crude and adjusted models. Confounding was considered present during model building when the percent difference between the parameter estimates was $\geq 10 \%$ (i.e., change in estimate approach) (VanderWeele 2019). Refer to Table 1 for details pertaining to variable operationalization and Appendix B for an overview of the bivariate analysis.

Table 1. Variable Operationalization.

\begin{tabular}{|c|c|c|}
\hline Variable & Survey Question & Operationalization \\
\hline Gender & $\begin{array}{c}\text { What is your gender? } \\
\text { Female } \\
\text { Male }\end{array}$ & $\begin{array}{c}\text { 0: Male } \\
\text { 1: Female }\end{array}$ \\
\hline Relationship Status & $\begin{array}{c}\text { What is your marital status? } \\
\text { Married or living together } \\
\text { Divorced/Separated from spouse } \\
\text { Widowed } \\
\text { Single, never married }\end{array}$ & $\begin{array}{c}\text { 0: Single } \\
\text { 1: In a relationship }\end{array}$ \\
\hline Education & $\begin{array}{l}\text { What is your highest educational qualification? } \\
\text { No formal education } \\
\text { Some primary school } \\
\text { Completed primary school } \\
\text { Some secondary school } \\
\text { Completed secondary school } \\
\text { Some post-secondary school } \\
\text { Completed post-secondary school }\end{array}$ & $\begin{array}{l}\text { 0: No education } \\
\text { 1: Some or completed primary school } \\
\text { 2: Some or completed secondary school } \\
\text { 3: Some or completed post-secondary }\end{array}$ \\
\hline
\end{tabular}


Table 1. Cont.

\begin{tabular}{|c|c|c|}
\hline Variable & Survey Question & Operationalization \\
\hline Income & $\begin{array}{c}\text { Please tell me which of these you or your } \\
\text { household owns. Your household consists of } \\
\text { people who sleep under the same roof and eat } \\
\text { the same meals. Chose as many as your family } \\
\text { has: } \\
\text { Radio } \\
\text { Mobile phone } \\
\text { Refrigerator or freezer } \\
\text { Vehicle such as a truck, car, or motorcycle } \\
\text { Generator, inverter, or a sun panel that provides } \\
\text { electricity to your home } \\
\text { None of the above }\end{array}$ & $\begin{array}{c}0: \text { Poor }(0-1 \text { items }) \\
\text { 1: Average }(2-3 \text { items }) \\
\text { 2: Well-off }(4-5 \text { items })\end{array}$ \\
\hline Age & $\begin{array}{l}\text { How old are you: } \\
11-17 \text { years old } \\
18-24 \text { years old } \\
25-34 \text { years old } \\
35-44 \text { years old } \\
45-54 \text { years old } \\
\geq 55 \text { years old }\end{array}$ & $\begin{array}{c}0:>45 \text { years } \\
1: 25-44 \text { years } \\
2: 11-24 \text { years }\end{array}$ \\
\hline
\end{tabular}

Who is the story about?

About me

About someone in my household

Who was the narrative about?

About someone in my family who doesn't live in

my household

About a friend

Community

Something I heard or read about
1: Poor $(0-1$ items $)$

1: Average (2-3 items)

2: Well-off (4-5 items)

What is the emotional tone of this story? Strongly positive

$\begin{array}{cc}\text { Positive } & 0: \text { Neutral } \\ \text { Neutral } & \text { 1: Positive } \\ \text { Negative } & \text { 2: Negative }\end{array}$

Emotional Tone

Negative

Very negative

In what location was the interview conducted?

[Question asked of the research assistants]

Location
Cite Soleil, Charlie Log Base/Tabarre, Gonaives, St. Marc, Hinche, Leogane, Port Salut,

Miragoane, Morne Casse/Fort Liberte, Cap Haitien
Cap Haitien (0), Charlie Log

Base/Tabarre (1), Cite Soleil (2), Hinche

(3), Leogane (4), Morne Casse/Fort

Liberte (5), Port Salut (6), Saint Marc (7)

For the model examining the geographical distribution of SEA, potential confounders identified a priori included gender, who the narrative was about, emotional tone, income, and age. Statistically significant relationships existed between each of the confounders and (i) geographical location (exposure) as well as (ii) whether a narrative about sexual misconduct was shared (outcome). For the model examining the desire to engage with the UN/MINUSTAH, the potential confounders identified a priori were gender, who the narrative was about, emotional tone, age, and location. Statistically significant relationships existed between each of the confounders and (i) narrative subject matter (exposure) as well as (ii) rejection of the UN/MINUSTAH (outcome).

Gender, who the narrative was about, and the narrative's emotional tone were conceptualized as important variables that differentiated the meaning and related perceptions of shared narratives in our sample. For the first objective, we considered effect modification of gender, emotional tone, and who the narrative was about. For the second objective we considered effect modification of gender and who the narrative was about. For example, in 
both models we were interested in exploring effect modification according to how close a narrative was to one's personal experiences (i.e., who the narrative was about). Effect modification was tested by including interaction terms in both models at the beginning of model building (i.e., in the full models) with a standard cut-off of $p<0.05$. A visual illustration of the exposure, outcome, and potential confounders, covariates, and effect modifiers for objective 1 and objective 2 are presented in Figure 1 and Figure 2, respectively.

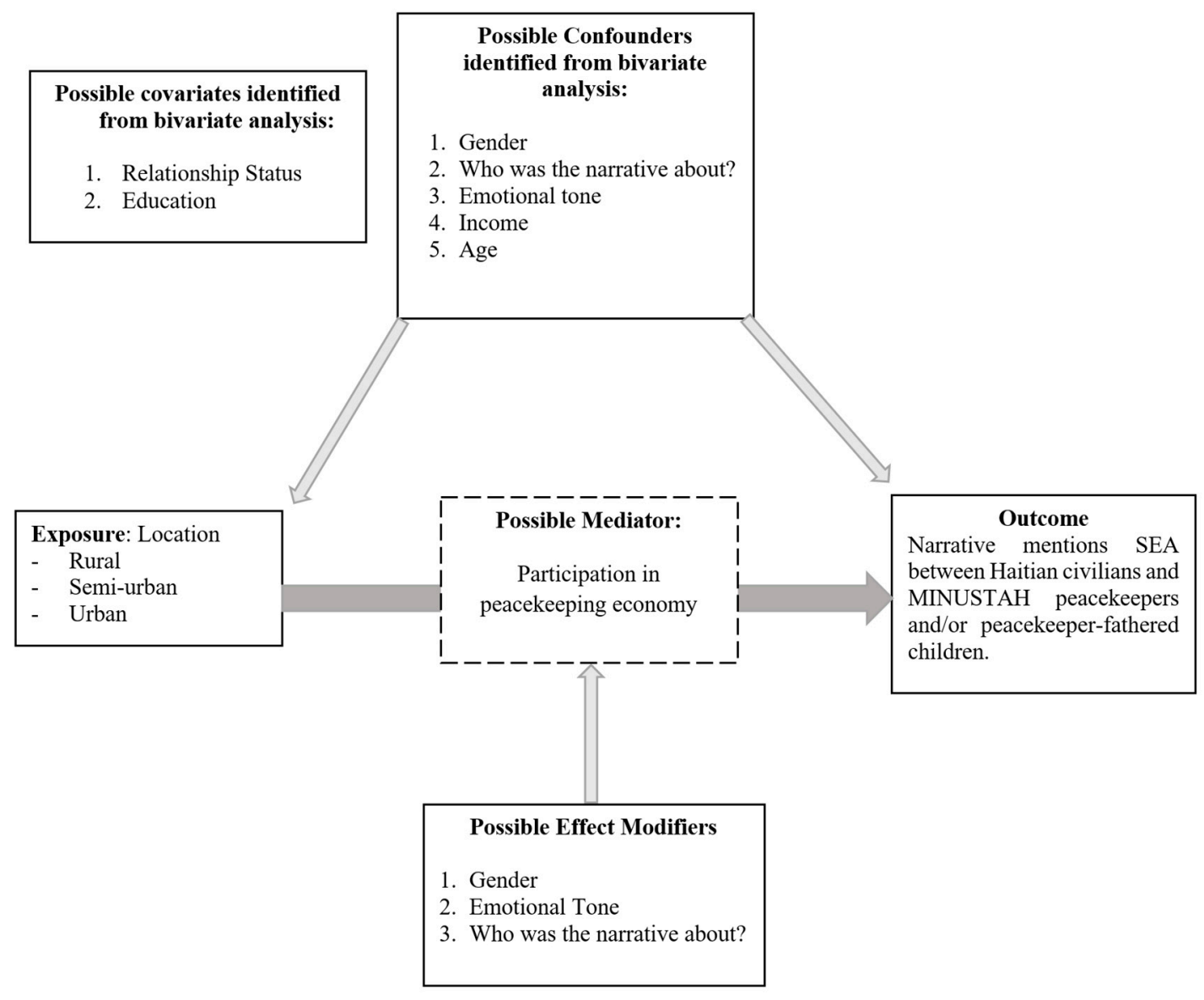

Note: Mediation analysis was not performed; figure illustrates all variables that were considered as potential confounders, covariates, and effect modifiers, not variables included in the final models.

Figure 1. Conceptual Model for Objective 1.

\subsection{Procedures}

The unit of observation for the two models was the narrative. Multivariate logbinomial regression modeled the relationships of interest because both outcome variables were operationalized as dichotomous/binary and were common ( $>10 \%$ prevalence). Moreover, we were interested in modeling the relative risk as opposed to the odds ratio (which cannot be interpreted as relative risk when the outcome is not rare) (Barros and Hirakata 2003; Luo et al. 2014). Accordingly, a log transformation was applied to both binary outcome measures. The goal was to build the most parsimonious model and identify any potential confounders or moderators; accordingly, a manual backwards elimination method was used during the model building (Heinze et al. 2018). Only variables that significantly contributed to predicting the outcomes (at a level of significance of 0.05), confounded, or moderated the relationship between the outcome and primary interest variables were included in the final models (Heinze et al. 2018). Multicollinearity was assessed at the bivariate and multivariate level. Multicollinearity was not deemed to be a concern because no variables were found to be highly correlated at the bivariate level, and variance inflation factors for non-interaction terms were less than 2. Detectable difference calculations were 
performed prior to data inspection and analysis. At $80 \%$ power and an alpha level of 0.05 , the smallest detectable difference ranged from 1.685 (most conservative) to 1.170 (most liberal). The data were analyzed using SAS 9.4.

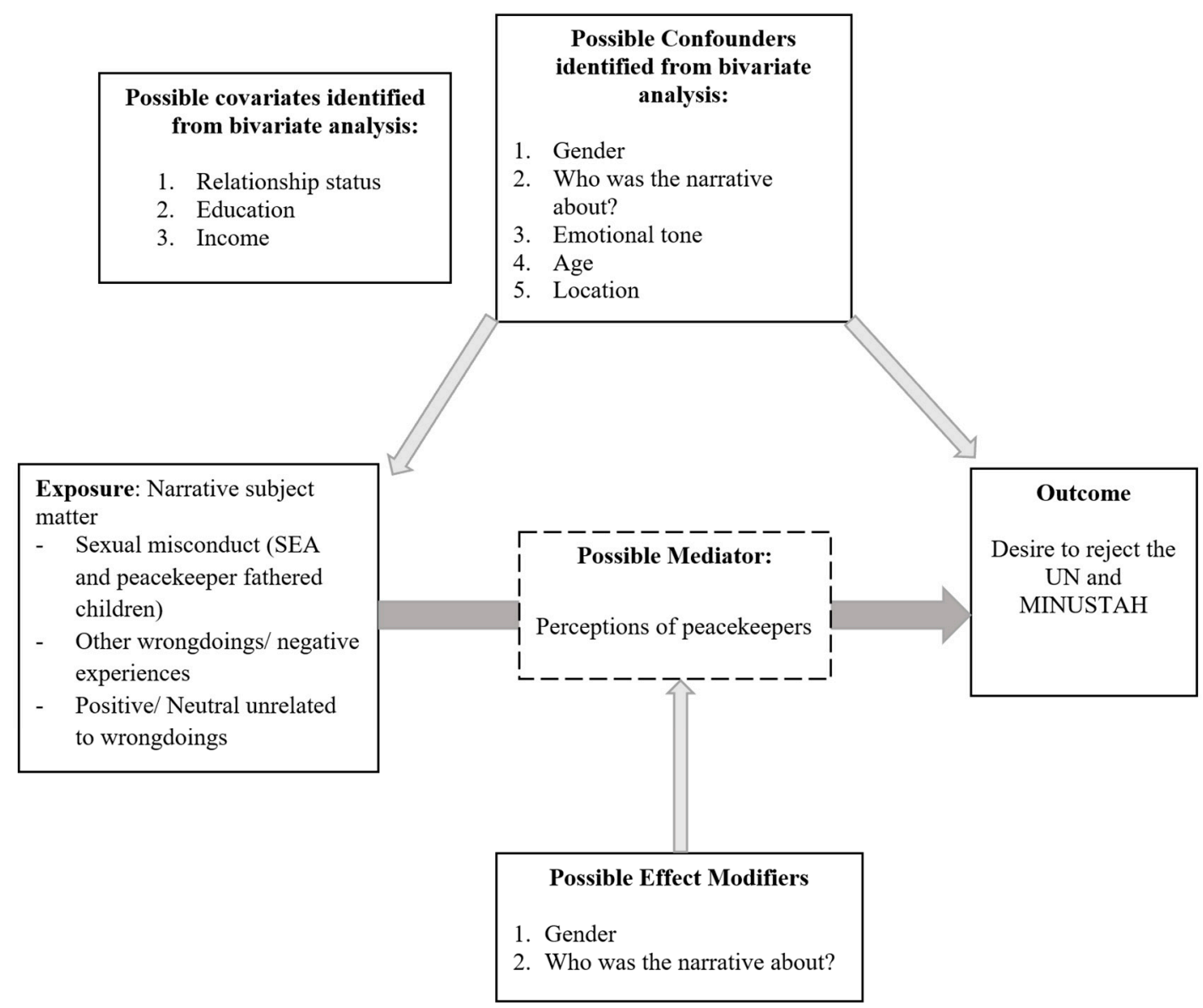

Note: Mediation analysis was not performed; figure illustrates all variables that were considered as potential confounders, covariates, and effect modifiers, not variables included in the final models.

Figure 2. Conceptional Model for Objective 2.

\subsection{Ethics}

Research ethics approval for the cross-sectional survey protocol and the present secondary analysis was obtained by the Queen's University Health Sciences and Affiliated Teaching Hospitals Research Ethics Board (\#6020398; \#6023714) and the University of Birmingham's Ethical Review Board (protocol ERN_16-0950). Prior to data collection, the Haitian community partner organizations, KOFAVIV, and BAI advised that there were no national legislative requirements to obtain local research ethics review in Haiti (Department of Health and Human Services 2020; Ministère de la Santé Publique 2020). Trained Haitian research assistants introduced the study to participants in Kreole using a standard script and informed consent was obtained prior to the start of the survey. All interviews were conducted confidentially, and the research assistants did not record identifying information. Participants indicated their consent by tapping a consent box on the tablet.

Given that the survey did not ask questions about SEA, participants could share any narrative they wanted, and there were no direct questions about SEA, the study was considered to involve minimal risk and written consent was waived. Adolescents aged 11 and older were included because they were known to be affected by SEA, and it would have been unethical to exclude them and their perspectives from the sample. Parental consent for the inclusion of minors was not sought because the adolescents were considered 
mature minors; involving parents would likely have introduced bias and risk for parental conflict and/or abuse if SEA or transactional sex was unknown to them (Weir 2019).

Additionally, team members from KOFAVIV, a grassroots Haitian organization for sexual violence survivors, were onsite to offer immediate support to participants, and all participants were offered referral to KOFAVIV, and to BAI for legal counsel, if needed. No compensation, financial or otherwise, was provided. To mitigate the risk of psychological distress, the survey intentionally did not ask participants to share experiences of sexual violence. No identifying information was collected, and it was requested of participants not to use the names of real people when reciting their experiences. To ensure data security, all completed surveys were uploaded from the tablets to a secure server and then were subsequently permanently deleted from the tablets.

\section{Results}

In total, 2541 self-interpreted narratives were collected from 2191 unique participants. After completing the cross-sectional questionnaire, participants were given the option to share and self-interpret an additional narrative (up to a maximum of four). Of the 2541 self-interpreted micro-narratives $n=276(10.9 \%)$ were second stories, $n=37(1.46 \%)$ were third stories, and $n=10(0.39 \%)$ were fourth stories shared by participants.

The majority of participants were male $(69.6 \%)$, single/never married $(60.5 \%)$, below the age of 35 years $(66.1 \%)$ and attained an income that was considered "average" (63.3\%), meaning they had access to two to three household items out of a possible five. Additional participant demographic characteristics are presented in Table 2.

Table 2. Demographic characteristics for total number of participants.

\begin{tabular}{|c|c|c|}
\hline Characteristic & $n$ & $\%$ \\
\hline \multicolumn{3}{|l|}{ Age } \\
\hline $11-17$ years old & 216 & 9.9 \\
\hline 18-24 years old & 508 & 23.2 \\
\hline 25-34 years old & 724 & 33.0 \\
\hline $35-44$ years old & 360 & 16.4 \\
\hline $45-54$ years old & 206 & 9.4 \\
\hline$\geq 55$ years old & 127 & 5.8 \\
\hline Prefer not to say & 48 & 2.2 \\
\hline Missing & 2 & 0.9 \\
\hline \multicolumn{3}{|l|}{ Gender } \\
\hline Male & 1526 & 69.6 \\
\hline Female & 664 & 30.3 \\
\hline Prefer not to say & 1 & 0.05 \\
\hline \multicolumn{3}{|l|}{ Education } \\
\hline No formal education & 118 & 5.4 \\
\hline Some primary school & 269 & 12.3 \\
\hline Completed primary school & 250 & 11.4 \\
\hline Some secondary school & 831 & 37.9 \\
\hline Completed secondary school & 416 & 19.0 \\
\hline Some post-secondary school & 217 & 9.9 \\
\hline $\begin{array}{l}\text { Completed post-secondary } \\
\text { school }\end{array}$ & 90 & 4.1 \\
\hline
\end{tabular}


Table 2. Cont.

\begin{tabular}{|c|c|c|}
\hline Characteristic & $n$ & $\%$ \\
\hline \multicolumn{3}{|l|}{ Income } \\
\hline Poor & 670 & 30.6 \\
\hline Average & 1386 & 63.3 \\
\hline Well-off & 135 & 6.2 \\
\hline \multicolumn{3}{|l|}{ Location $^{a}$} \\
\hline Cité Soleil & 341 & 15.6 \\
\hline Port Salut & 313 & 14.3 \\
\hline Saint Marc and Gonaives & 314 & 14.3 \\
\hline Leogane & 314 & 14.3 \\
\hline Hinche & 303 & 13.8 \\
\hline Cap Haitien & 246 & 11.2 \\
\hline Morne Casse and Fort Liberté & 192 & 8.8 \\
\hline Charlie Log Base and Tabarre & 168 & 7.7 \\
\hline \multicolumn{3}{|l|}{ Marital Status } \\
\hline Single never married & 1326 & 60.5 \\
\hline $\begin{array}{l}\text { Married or living together as } \\
\text { if married }\end{array}$ & 796 & 36.3 \\
\hline $\begin{array}{l}\text { Divorced/Separated from } \\
\text { spouse }\end{array}$ & 18 & 0.8 \\
\hline Widowed & 15 & 0.7 \\
\hline Prefer not to say & 36 & 1.6 \\
\hline \multicolumn{3}{|c|}{$n_{\text {total }}=2191$ Narrators $/$ Participants } \\
\hline
\end{tabular}

a Port-au-Prince data collection sites consisted of Cité Soleil, Charlie Log Base, and Tabarre.

\subsection{Characteristics of the Narratives Shared}

Of the 2541 self-interpreted narratives, $680(27 \%)$ addressed sexual misconduct perpetrated by MINUSTAH peacekeepers. As demonstrated in Table 2, 74\% of narratives about sexual misconduct were shared by Haitian men, mirroring the general sex distribution among the participants (Table 1). Compared to narratives that did not address sexual misconduct by MINUSTAH peacekeepers, narratives addressing sexual misconduct were more likely to be collected in Port Salut and Cité Soleil, more likely to be identified as being "about someone else in my community", and less likely to be identified as first-hand experiences experienced directly by the research participant (Table 3). Moreover, narratives addressing sexual misconduct were more likely to have a "negative" and "very negative" emotional tone, as identified by the participant. Participants were also more likely to respond that "others must hear this story and take action" if they shared a narrative addressing sexual misconduct. Lastly, Uruguayan peacekeepers were more likely to be identified in narratives about sexual misconduct. 
Table 3. Characteristics of the narratives shared.

\begin{tabular}{|c|c|c|c|c|}
\hline Characteristic & All Narratives $n(\%)$ & Sexual Misconduct & No Sexual Misconduct & $p$-Value * \\
\hline Location & $n=2541$ & $n=682$ & $n=1859$ & \multirow{9}{*}{$<0.0001$} \\
\hline Cité Soleil & $399(15.7)$ & $129(18.9)$ & $270(14.5)$ & \\
\hline Port Salut & $364(14.3)$ & $180(26.4)$ & $184(9.9)$ & \\
\hline Saint Marc and Gonaïves & $361(14.2)$ & $102(15)$ & $259(13.9)$ & \\
\hline Hinche & $359(14.1)$ & 91 (13.3) & $268(14.4)$ & \\
\hline Léogâne & $355(14.0)$ & $62(9.1)$ & $293(15.8)$ & \\
\hline Cap Haiïtien & $287(11.3)$ & $54(7.9)$ & $233(12.5)$ & \\
\hline $\begin{array}{c}\text { Morne Casse and Fort } \\
\text { Liberté }\end{array}$ & $220(8.7)$ & $25(3.7)$ & $195(10.5)$ & \\
\hline $\begin{array}{c}\text { Charlie Log Base and } \\
\text { Tabarre }\end{array}$ & $196(7.7)$ & $39(5.7)$ & $157(8.4)$ & \\
\hline Gender of narrator & $n=2539$ & $n=680$ & $n=1859$ & \multirow{3}{*}{0.0370} \\
\hline Male & $1803(71.0)$ & $504(74.1)$ & $1299(69.9)$ & \\
\hline Female & $736(29)$ & $176(25.8)$ & $560(30.1)$ & \\
\hline Location by subgroup & $n=2541$ & $n=682$ & $n=1859$ & \multirow{4}{*}{$<0.0001$} \\
\hline $\operatorname{Urban}^{\varphi}$ & $595(23.4)$ & $168(24.6)$ & $427(23.0)$ & \\
\hline Semi-urban ${ }^{\Upsilon}$ & $642(25.2)$ & $116(17.0)$ & $526(28.3)$ & \\
\hline Rural $\perp^{\perp}$ & $1304(51.3)$ & $398(58.4)$ & $906(48.7)$ & \\
\hline $\begin{array}{l}\text { Willingness to Engage } \\
\text { with UN }\end{array}$ & $n=2314$ & $n=652$ & $n=1662$ & \multirow{3}{*}{$<0.0001$} \\
\hline Reject UN/MINUSTAH & $1132(48.9)$ & $219(33.6)$ & $963(57.4)$ & \\
\hline $\begin{array}{l}\text { Engage with the } \\
\text { UN/MINUSTAH }\end{array}$ & $1182(51.1)$ & $433(66.4)$ & $699(42.0)$ & \\
\hline Who is this story about? & $n=2493$ & $n=682$ & $n=1859$ & \multirow{8}{*}{$<0.0001$} \\
\hline Friend & $109(4.3)$ & $62(9.1)$ & $47(2.5)$ & \\
\hline $\mathrm{Me}$ & $890(35.0)$ & $83(12.2)$ & $807(43.4)$ & \\
\hline $\begin{array}{l}\text { Someone else in my } \\
\text { community }\end{array}$ & $1000(39.4)$ & $395(57.9)$ & $605(32.5)$ & \\
\hline $\begin{array}{c}\text { Someone in my family who } \\
\text { does not live in my } \\
\text { household }\end{array}$ & $51(2.0)$ & $19(2.8)$ & $32(1.7)$ & \\
\hline Someone in my household & $55(2.2)$ & $19(2.8)$ & $36(1.9)$ & \\
\hline Something I heard or read & $388(15.3)$ & $93(13.6)$ & $295(15.9)$ & \\
\hline Prefer not to say & $48(1.9)$ & $11(1.6)$ & $37(2.0)$ & \\
\hline Emotional Tone & $n=2541$ & $n=682$ & $n=1859$ & \multirow{7}{*}{$<0.0001$} \\
\hline Very negative & $257(10.1)$ & $133(19.5)$ & $124(6.7)$ & \\
\hline Negative & $909(35.8)$ & $313(45.9)$ & $596(32.1)$ & \\
\hline Neutral & $278(10.9)$ & $68(10.0)$ & $210(11.3)$ & \\
\hline Not sure & $44(1.7)$ & $7(1.0)$ & $37(2.0)$ & \\
\hline Positive & $826(32.5)$ & $108(15.8)$ & 718 (38.6) & \\
\hline Strongly positive & $227(8.93)$ & $53(7.8)$ & $174(9.4)$ & \\
\hline
\end{tabular}


Table 3. Cont.

\begin{tabular}{|c|c|c|c|c|}
\hline Characteristic & All Narratives $n(\%)$ & Sexual Misconduct & No Sexual Misconduct & $p$-Value * \\
\hline $\begin{array}{l}\text { How often does this } \\
\text { situation occur? }\end{array}$ & $n=2541$ & $n=682$ & $n=1859$ & \multirow{7}{*}{$<0.0001$} \\
\hline All the time & $408(16.1)$ & 95 (13.9) & $313(16.8)$ & \\
\hline Very frequently & $943(37.1)$ & $265(38.9)$ & $678(36.5)$ & \\
\hline Regularly & $469(18.5)$ & $137(20.1)$ & $332(17.9)$ & \\
\hline Occasionally & $258(10.2)$ & $95(13.9)$ & $163(8.8)$ & \\
\hline Very rarely & $300(11.8)$ & $75(11)$ & $225(12.1)$ & \\
\hline Not sure & $163(6.4)$ & $15(2.2)$ & $148(8.0)$ & \\
\hline $\begin{array}{l}\text { How important is it for } \\
\text { others to hear your story? }\end{array}$ & $n=2541$ & $n=682$ & $n=1859$ & \multirow{6}{*}{$<0.0001$} \\
\hline $\begin{array}{c}\text { Must hear this story and } \\
\text { take action }\end{array}$ & $1522(59.9)$ & $515(75.5)$ & 1007 (54.2) & \\
\hline $\begin{array}{l}\text { Should definitely hear this } \\
\text { story and pay attention }\end{array}$ & $689(27.1)$ & $137(20.1)$ & $552(29.7)$ & \\
\hline $\begin{array}{c}\text { Can learn some things but } \\
\text { not much }\end{array}$ & $268(10.6)$ & $22(3.2)$ & $246(13.2)$ & \\
\hline $\begin{array}{l}\text { Nothing to learn from this } \\
\text { story }\end{array}$ & $15(0.59)$ & $3(0.4)$ & $12(0.6)$ & \\
\hline Not sure & $47(1.85)$ & $5(0.7)$ & $42(2.3)$ & \\
\hline $\begin{array}{l}\text { What country was the } \\
\text { foreigner in the story } \\
\text { from? }\end{array}$ & $n=2541$ & $n=682$ & $n=1859$ & \multirow{12}{*}{$<0.0001$} \\
\hline Uruguay & $395(15.6)$ & $167(24.5)$ & $228(12.3)$ & \\
\hline Brazil & $522(20.5)$ & $150(22.0)$ & $372(20.0)$ & \\
\hline Chile & $257(10.1)$ & $50(7.3)$ & $207(11.1)$ & \\
\hline Argentina & $182(7.2)$ & $51(7.5)$ & $131(7.0)$ & \\
\hline Nepal & $227(8.9)$ & $49(7.2)$ & $178(9.6)$ & \\
\hline Sri Lanka & $142(5.5)$ & $28(4.1)$ & $114(6.1)$ & \\
\hline United States & $26(1.0)$ & $2(0.3)$ & $24(1.3)$ & \\
\hline Canada & $12(0.5)$ & $4(0.6)$ & $8(0.4)$ & \\
\hline Bolivia & $9(0.4)$ & $2(0.3)$ & $7(0.4)$ & \\
\hline Don't know & $517(20.4)$ & $120(17.6)$ & $397(21.4)$ & \\
\hline Other $\$$ & $252(9.91)$ & $59(8.65)$ & $193(10.38)$ & \\
\hline
\end{tabular}

‘* $p$-value for Pearson Chi-square test for categorical variables comparing narratives about sexual misconduct to narratives unrelated to sexual misconduct. ${ }^{\varphi}$ Urban category included: Cité Soleil, Charlie Log Base, and Tabarre. ${ }^{\Upsilon}$ Semi-urban category: Léogâne and Cap Haiitien. ${ }^{\perp}$ Rural category: St. Marc, Gonaives, Morne Casse, Fort Liberté, Hinche and Port Salut. § Other: China, France, Indonesia, Japan, Jordan, Nigeria, Other, Pakistan, Peru, Senegal.

\subsection{Geographical Distribution of Narratives about Sexual Misconduct}

As illustrated in Table 4, compared to urban locations, narratives shared in rural locations had an increased probability $(\mathrm{RR}=1.19$ [95\% CI:1.03, 1.38]) of addressing sexual misconduct. Compared to urban locations, narratives shared in semi-urban locations had a decreased probability of addressing sexual misconduct ( $R R=0.70$ [95\% CI: 0.57, 0.86]). Therefore, after adjustment, the probability of expressing a narrative about sexual misconduct was greatest in rural locations, followed by urban locations, and semi-urban locations had the least probability of mentioning sexual misconduct. 
Table 4. Association between geographical location and narratives addressing sexual misconduct.

\begin{tabular}{cccc}
\hline Exposure & RR & $\mathbf{9 5 \%} \mathbf{C I}$ & $p$-Value \\
\hline Location & & $<0.0001$ \\
\hline Urban & 1.00 & Ref & Ref \\
\hline Semi-Urban & 1.19 & $(1.03,1.38)$ & 0.0195 \\
\hline
\end{tabular}

126 narratives were excluded due to missing covariates $\left(n_{\text {total }}=2415\right)$. Model adjusted for: emotional tone, who is this narrative about, and age of narrator. $\mathrm{RR}=$ Relative Risk; $\mathrm{CI}=$ Confidence Interval.

\subsection{Association between Sexual Misconduct and Willingness to Engage with the UN}

In general, after adjustment, we found a positive association between narratives of sexual misconduct and the desire to reject the UN/MINUSTAH. A similar positive association was also noted between narratives of wrongdoings unrelated to sexual misconduct and the desire to reject the UN/MINUSTAH. Interestingly, the association between subject matter of the narrative and desire to reject the UN was modified by who the narrative was about $(p$-value $=0.0113$ for interaction term). We depict the statistical interaction visually in Figure 3.

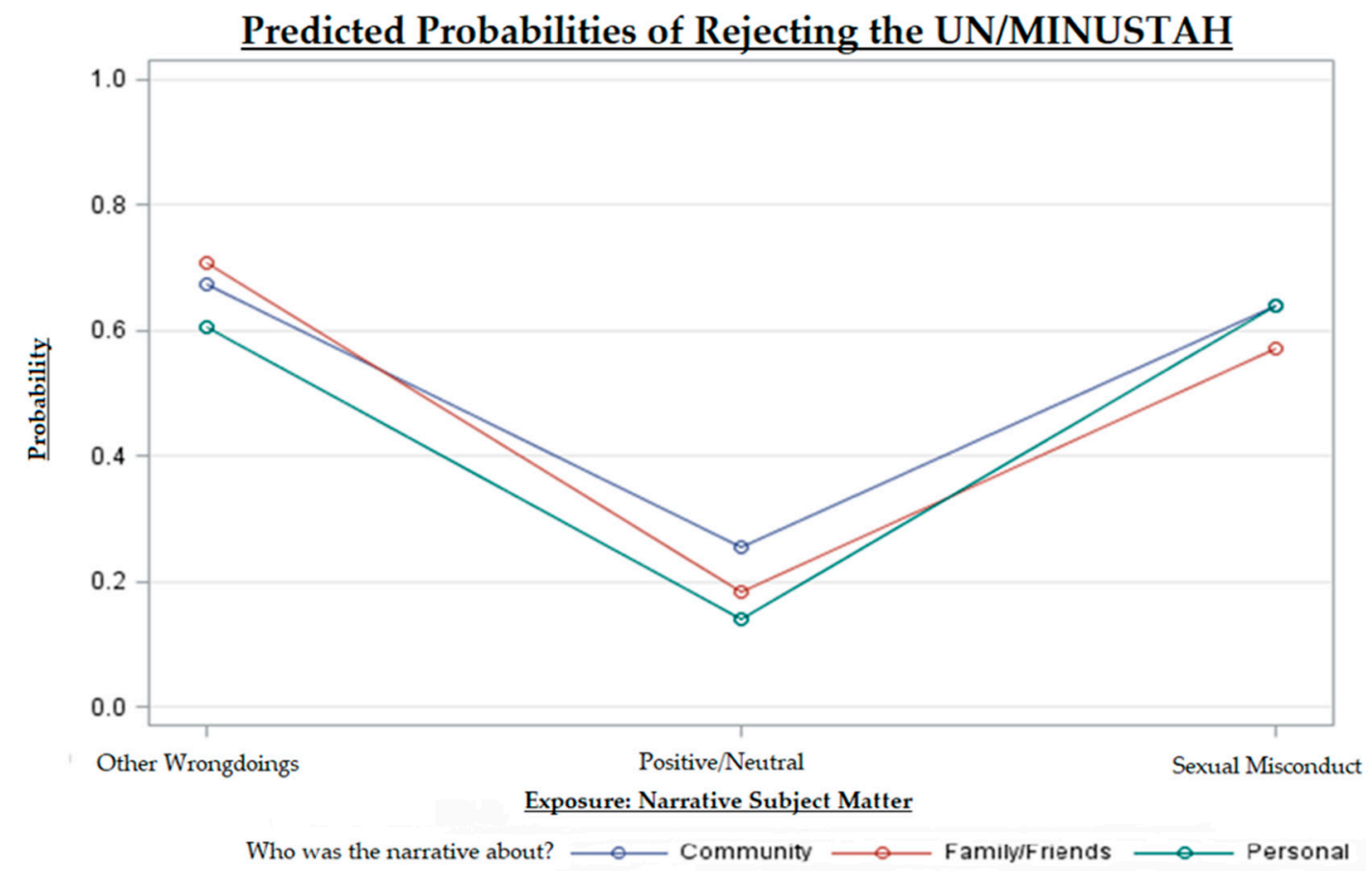

Model adjusted for: narrator relationship status (referent=single), narrator income (referent=poor), narrator gender (referent=male), and emotional tone of the narrative (referent=neutral). The predicted probabilities are computed using the referent group for each covariate controlled. Interaction term (narrative*who is the story about) $\mathrm{p}$-value $=0.0113$

Figure 3. Interaction plot of narrative subject and predicted probability of rejecting the UN/MINUSTAH, stratified by who the narrative is about *.

This statistically significant interaction reveals that while general positive associations are noted, the magnitude of the association differs by who experienced the misconduct (Table 5). The heterogeneity of effect was identified between the personal stratum and community stratum. Regarding personal narratives, narrators of stories about experiences of sexual misconduct had 4.52 (95\% CI: 3.34, 6.12) times the probability of rejecting the UN/MINUSTAH compared to narrators who shared positive/neutral experiences. Regard- 
ing narratives about community members, narrators of experiences about sexual misconduct had 2.51 (95\% CI: 2.00, 3.14) times the probability of rejecting the UN/MINUSTAH compared to narrators who shared positive/neutral experiences. These results suggest that first-hand experiences of sexual misconduct perpetrated by peacekeepers had the most extreme effect on the probability of rejecting the UN/MINUSTAH. When comparing the effect of narratives about sexual misconduct to narratives about other wrongdoings on the probability of rejecting the UN/MINUSTAH, no statistically significant differences were noted (Table 6).

Table 5. Association between narrative subject matter and the probability of rejecting the UN/MINUSTAH stratified by who the narrative is about.

\begin{tabular}{|c|c|c|c|c|c|c|}
\hline & \multicolumn{6}{|c|}{ Who Is This Story about? } \\
\hline & \multicolumn{2}{|c|}{ Community Members $(n=1388)$} & \multicolumn{2}{|c|}{ Family \& Friends $(n=215)$} & \multicolumn{2}{|c|}{ Personal $(n=890)$} \\
\hline & RR $(95 \%$ CI) & $p$-Value & RR $(95 \%$ CI) & $p$-Value & RR $(95 \%$ CI) & $p$-Value \\
\hline Positive/Neutral & \multicolumn{2}{|c|}{ Ref } & \multicolumn{2}{|c|}{ Ref } & \multicolumn{2}{|c|}{ Ref } \\
\hline $\begin{array}{c}\text { Other } \\
\text { wrongdoings }\end{array}$ & $2.64(2.11,3.31)$ & $<0.0001$ & $3.84(1.69,8.74)$ & 0.0013 & $4.28(3.22,5.67)$ & $<0.0001$ \\
\hline $\begin{array}{c}\text { Sexual } \\
\text { Misconduct }\end{array}$ & $2.51(2.00,3.14)$ & $<0.0001$ & $3.12(1.35,7.11)$ & 0.0072 & $4.52(3.34,6.12)$ & $<0.0001$ \\
\hline
\end{tabular}

310 narratives were removed from this analysis due to incomplete covariate information $\left(\mathrm{N}_{\text {total }}=2231\right)$. Interaction term (subject matter of narrative ${ }^{*}$ who is the story about) $p$-value $=0.0113$. Log-binomial model is adjusted for: narrator income, narrator gender, narrator relationship status and the narrative's emotional tone. $\mathrm{RR}=$ Relative Risk; $\mathrm{CI}=$ Confidence Interval

Table 6. Comparison between narratives addressing peacekeeper misconduct or not and the probability of rejecting the UN/MINUSTAH stratified by who the narrative is about.

\begin{tabular}{|c|c|c|c|c|c|c|}
\hline \multirow{3}{*}{$\begin{array}{c}\text { Narrative } \\
\text { Subject Matter }\end{array}$} & \multicolumn{6}{|c|}{ Who Is This Narrative about? } \\
\hline & \multicolumn{2}{|c|}{ Community Members $n=1388$} & \multicolumn{2}{|c|}{ Family \& Friends $n=215$} & \multicolumn{2}{|c|}{ Personal $n=890$} \\
\hline & RR $(95 \%$ CI) & $p$-Value & $\operatorname{RR}(95 \% \mathrm{CI})$ & $p$-Value & RR (95\% CI) & $p$-Value \\
\hline $\begin{array}{c}\text { Sexual } \\
\text { Misconduct }\end{array}$ & \multicolumn{2}{|c|}{ Ref } & \multicolumn{2}{|c|}{ Ref } & \multicolumn{2}{|c|}{ Ref } \\
\hline $\begin{array}{c}\text { Other } \\
\text { wrongdoings }\end{array}$ & $1.05(0.97,1.14)$ & 0.1946 & $1.24(1.01,1.52)$ & 0.0481 & $0.95(0.80,1.13)$ & 0.5313 \\
\hline
\end{tabular}

310 narratives were removed from this analysis due to incomplete covariate information $\left(\mathrm{N}_{\text {total }}=2231\right)$ Interaction term (narrative ${ }^{*}$ who is the story about) $p$-value $=0.0113$. Log-binomial model is adjusted for narrator income, narrator gender, narrator relationship status and the narrative's emotional tone. $\mathrm{RR}=$ Relative Risk; $\mathrm{CI}$ = Confidence Interval

\section{Discussion}

The purpose of this research was to generate empirical understandings of peacekeeperperpetrated sexual misconduct during MINUSTAH through a secondary analysis of 2541 self-interpreted narratives obtained from Haitian community members who lived in proximity to MINUSTAH peacekeeping bases. The results must be interpreted considering the convenience sampling employed and reliance on secondary data.

\subsection{Geographic Distribution of Sexual Misconduct Perpetrated by Peacekeepers}

After adjusting for narrator age, emotional tone of the narrative, and who the narrative was about, compared to urban locations the probability of sharing a narrative about sexual misconduct was greater in rural locations and less in semi-urban locations.

Peacekeeping economies may explain why narratives shared in rural locations had a greater probability of mentioning sexual misconduct compared to urban locations. Given that women and girls in rural Haiti face greater socioeconomic disparities compared to their urban counterparts (Institut Haïtien de l'Enfance 2018), their reliance on peacekeeping economies to support their livelihoods was hypothesized to be greater, potentially leading 
to a variety of sexual interactions with peacekeepers: transactional sex, commercial sex work, long-term relationships, and SEA. Thus, we expected the narratives about sexual misconduct to be greater in rural locations, compared to urban locations.

However, the mechanism of peacekeeping economies does not consider the conduct and discipline of peacekeepers within each base. The rural-effect may also be explained by the differential implementation of sexual misconduct deterrence measures such as the zerotolerance policy, SEA reporting mechanisms, surveillance, and peacekeeper discipline. The certainty of punishment has been identified as an important factor in deterring potential SEA perpetrators during PO (Neudorfer 2014).

Narratives about children fathered by peacekeepers were included in the sexual misconduct outcome. The mechanism of peacekeeping economies does not fully address the existence of children fathered by MINUSTAH peacekeepers. The rural-effect may be more fully explained by considering differential access to resources and information between urban and rural locations, such as contraception needs and access to abortion. Narratives that mention children fathered by peacekeepers might be shared to a greater extent in rural locations because women and girls in rural Haiti could be more at risk of conceiving children with peacekeepers on account of unmet contraception needs or inability to access abortion.

The current sample is not exclusively comprised of first-person narratives. The inclusion of narratives about family/friends or community members may speak to differing social dynamics such as comfort speaking about the experiences of other people and the ease with which information travels through a community. Moreover, the presence of peacekeepers and the phenomena of sexual interactions with peacekeepers may be more novel in rural locations compared to urban locations, resulting in more narratives about sexual misconduct being shared in rural locations. In conclusion, the rural effect identified is likely a multicausal phenomenon that is only partially explained by the participation of women and girls in peacekeeping economies. Future research should aim to further elucidate the variability of SEA-related narratives/experiences attributable to geographical location using more rigorous sampling strategies that collect probability samples as opposed to convenience samples of narratives. The geographical distribution of SEA could have implications for how the UN allocates conduct and discipline resources and where it focuses its SEA prevention training.

No other studies have examined the distribution of narratives/experiences about peacekeeper-perpetrated sexual misconduct by urban, rural, and semi-urban locations. However, research that applies regression modelling to peacekeeping data over multiple mission years exists. Some parallels can also be drawn to the work of Nordås and Rustad (2013) who identified host-country risk factors of reported SEA. Low GDP per capita, high level of pre-conflict sexual violence, and absence of spousal rape law were positively associated with reported SEA. Similarly, Moncrief (2017) found increasing host-country GDP per capita was significantly related to reduced SEA allegations. Finally, Neudorfer (2014) investigated whether the presence of conduct and discipline units (CDUs) were associated with reduced SEA allegations. The author concluded that the introduction of a conduct and discipline unit in $\mathrm{PO}$ was negatively and significantly correlated with the number of SEA allegations. Given the distribution of sexual misconduct narratives, it might be prudent to decentralize the CDU within a given PO such that CDUs are also placed in at-risk locations.

Elucidating the geographical distribution of SEA in Haiti advances the understanding of locations where Haitians hold strong views on SEA and where narratives/experiences of SEA are most likely to be expressed. While the UN no longer has an active peacekeeping presence in Haiti since the 2019 termination of the United Nations Mission for Justice Support in Haiti and the recent assassination of President Jovenel Moïse, the country continues to face prolonged and consistent insecurity (Porter et al. 2021). Currently, it is unknown whether the UN plans to reinstate a future PO in Haiti. However, it is clear that the UN has a 25-year history of deploying PO in Haiti (Diehl 2008), resulting in a 
"humanitarian economy". Thus, diligence in understanding regions within Haiti where community members express narratives/experiences of sexual misconduct perpetrated by peacekeepers and foreign humanitarian actors is a prudent first step in rebuilding community partnerships.

Not only could deterrence measures such as CDUs be implemented, but also interventions that address the social and economic factors that increase the vulnerability of experiencing SEA or participating in peacekeeping economies, as well as programs such as the UN Trust Fund for SEA victims that support the transitional justice of SEA survivors and their peacekeeper-fathered children (United Nations 2019; Connors 2019). Approaches to preventing and responding to SEA exist on a spectrum, from targeting peacekeepers to targeting local women and girls (Spangaro et al. 2013). By recognizing the geographical distribution of SEA narratives, actionable intervention areas can be identified.

We also advocate for the UN to consult with national and regional sectors in Haiti involved in the prevention, response, and support of SEA survivors and to build linkages that better integrate community-level experiences and perceptions within such programming. National and regional Haitian sectors can play a key role in guiding sustainable programmes and developing new policies to prevent SEA, providing adequate responses to victims/survivors in the context of PKO in Haiti, and holding peacekeepers accountable. In the absence of an evidence-based approach with respect to the allocation of deterrence and prevention policies and programs, sexual misconduct perpetrated by MINUSTAH peacekeepers has the potential to further tarnish the UN's legitimacy in host countries.

\subsection{Impact of Sexual Misconduct on the Desire to Engage with the UN}

After adjusting for income, gender, emotional tone, and relationship status, we found positive associations between experiences of peacekeeper misconduct (both related to sexual misconduct and not) and the desire to reject the UN/MINUSTAH. The association between subject-matter of the narrative and desire to reject the UN was modified by who the narrative was about. This statistically significant interaction revealed that while general positive associations are noted, the strength of the association differed by who experienced the misconduct.

The non-overlapping 95\% confidence intervals demonstrate that the RR point estimates comparing sexual misconduct to positive/neutral experiences were statistically different between the personal and community strata. These results suggest that first-hand experiences of sexual misconduct perpetrated by peacekeepers had the most extreme effect on the probability of rejecting the UN/MINUSTAH. Due to a lower sample size in the family / friends stratum $(n=215)$, the imprecise CI $(95 \%$ CI: 1.35, 7.11) surrounding the point estimates for the family/friends stratum prevented meaningful inferences regarding the heterogeneity of effect (Table 5).

Exposure to everyday experiences with peacekeepers will shape civilian perceptions of peacekeepers, which in turn affects the desire to engage with peacekeepers (Gordon and Young 2017). Local civilians may not have access to reliable information about peacekeepers (Talentino 2007); they rely on personal, vicarious, and community-level experiences regarding the day-to-day activities of peacekeepers. Thus, experiences with peacekeepers influence perceptions, thereby impacting decisions related to engaging with the UN/MINUSTAH.

Using a rigorous random sampling strategy, Gordon and Young found that exposure to abuse perpetrated by peacekeepers negatively affected perceptions related to the effectiveness, abusiveness, and benevolence of peacekeepers (Gordon and Young 2017). Negative perceptions of peacekeepers were found to reduce cooperation with peacekeepers, measured through information sharing. The earlier work of Gordon and Young suggested perceptions of peacekeepers mediate the relationship between narratives of sexual misconduct and the probability of rejecting the UN/MINUSTAH. Furthermore, exposure to abuses perpetrated by peacekeepers were negatively associated with cooperation with peacekeepers, in terms of information sharing and crime reporting. Likewise, the current 
results indicate that exposure to misconduct perpetrated by peacekeepers increased the probability of rejecting the UN/MINUSTAH, compared to positive/neutral experiences with peacekeepers.

Gordon and Young aggregated a variety of abuses perpetrated by MINUSTAH peacekeepers into one category: excessive use of force, theft, sexual exploitation, and domestic abuse (Gordon and Young 2017). The present analysis builds on that of Gordon and Young because it disaggregated misconduct perpetrated by peacekeepers into two categories: sexual misconduct and other wrongdoings. This allowed for the separation of effect between sexual misconduct and other wrongdoings perpetrated by peacekeepers on the probability of rejecting the UN/MINUSTAH. The disaggregation by misconduct type did not reveal statistically significant differences on the probability of rejecting the UN/MINUSTAH (Table 6). In addition, the present results expand the mechanism proposed by Gordon and Young by considering effect modification according to whether experiences with peacekeepers were first-hand or vicarious (about others such as, family/friends or community members). The results suggested that first-hand experiences of sexual misconduct perpetrated by peacekeepers had a more extreme effect on the probability of rejecting the UN/MINUSTAH. Therefore, the closer in proximity experiences to sexual misconduct are, the greater the probability of rejecting the UN/MINUSTAH. In other words, first-hand and vicarious experiences of sexual misconduct are distinct lived experiences that have differential effects on the desire to engage with the UN/MINUSTAH.

The UN's continued presence in Haiti, either through PO or other UN organizations, is negatively affected by MINUSTAH's legacy of sexual misconduct. The present analysis makes the case that sexual misconduct perpetrated by peacekeepers not only affects the individuals who experience abuse and exploitation but also the individuals' social networks and communities. MINUSTAH's legacy in Haiti is interconnected with narratives of SEA and negative sentiments related to the willingness to engage with the UN. Future PO and humanitarian actors deployed to Haiti will live and work in regions where local community members have deeply entrenched perceptions, sentiments, and attitudes that diminish cooperation and trust. This is likely to affect the legitimacy of future UN operations in Haiti, thereby destabilizing long-term peacebuilding and democratization agendas. In addition, the desire to reject the UN may also translate to the UN's multilateral organizations that also operate in Haiti-World Food Programme, United Nations Children's Fund, United Nations Population Fund — and humanitarian organizations such as Oxfam and Doctors without Borders. To this end, it is important for national and regional Haitian sectors involved in violence prevention efforts to play a central role in peace-building agendas with respect to responding to and integrating community-level perceptions, attitudes, and beliefs, particularly those of SEA survivors.

\subsection{Limitations}

The results must be interpreted with several limitations in mind. Due to prolonged political instability and earthquake-related losses such as mass death, displacement, and weak infrastructure, the 2003 Haitian census is not usable (Gordon and Young 2017). Consequently, a sampling frame of the Haitian population living in proximity to peacekeeping bases is difficult to acquire. The purposeful and convenience sampling strategies employed are not ideal for generalising results to the Haitian population at large. Nevertheless, a large sample of Haitians living in proximity to MINUSTAH bases was obtained. Compared to the 2016-2017 DHS, a greater proportion of participants in the sample achieved higher levels of education, attained average income, were male, and were single/never married. Therefore, the sample obtained for the cross-sectional survey was not an accurate representation of the Haitian population at large, based on 2016-2017 DHS data, but may be more reflective of Haitians living near MINUSTAH bases, who were out in public spaces or who were likely to participate in the research.

Convenience sampling has the potential to introduce selection bias. The gender imbalance noted in the sample $(70 \%$ males, $30 \%$ females) is the result of participants' 
self-selection out of the study. Research assistants recruited participants in public and community settings during the day: markets, post offices, and bus stops. This may have reduced the probability of recruiting certain members of the population: women responsible for domestic duties, persons living with disabilities, and older adults.

Second, narratives shared by the participants sometimes addressed more than one distinct experience with MINUSTAH peacekeepers. Consequently, the classification of single narratives that addressed multiple experiences into distinct subject matter categories was challenging. Narratives that contained descriptions of sexual interactions in addition to other experiences were classified as being about sexual misconduct. This classification may be related to the outcome because experiences of sexual misconduct alongside other wrongdoings may have a more profound and extreme effect on the desire to reject the UN/MINUSTAH. Finally, due to the secondary nature of the data, we did not have access to variables useful for model building, including the mediators identified in Figures 1 and 2 and other confounders. We would have liked to consider a number of additional confounders: earthquake-related losses, community social cohesion, number of internally displaced persons, composition and size of peacekeeping contingent peacekeeper gender and SEA training, TPCC laws against marital rape, etc.

Due to the limitations, the analyses presented should be seen as exploratory because there is little causal research to date examining the distribution and consequences of sexual misconduct perpetrated by peacekeepers. The results from both models explain associations rather than causal mechanisms. To further support the implementation of evidence-based policies and programs, more rigorous population-based studies using sampling strategies (Gordon and Young 2017; Beber et al. 2017) that examine target intervention areas in Haiti and the effect of experiencing sexual misconduct on the willingness to engage with the UN should be conducted.

\subsection{Strengths and Contributions}

This research contributes to the growing field of scholarship at the intersection of epidemiology and peacekeeping. In contrast to traditional cross-sectional questionnaires implemented in host countries, this research utilizes SenseMaker to capture the complex, nuanced, multifaceted phenomenon of SEA. SenseMaker allowed for the rapid collection of mixed-methods data, between June and August of 2017, which included 2541 narratives about the experiences of women and girls in relation to MINUSTAH from a variety of community members.

The nature of SEA during MINUSTAH merits specific analysis given that sexual violence perpetrated by UN peacekeepers in Haiti exists within the context of intra-state violence and earthquake-related losses. Therefore, this work provides in-depth and contextualized analysis of how sexual relations with peacekeepers operated in Haiti as an alternative to the analysis of SEA count data aggregated over multiple peacekeeping missions and host countries. Similar to sexual violence more broadly, sexual misconduct perpetrated by peacekeepers is a widely unreported crime; accounts of SEA that are formally reported to the UN represent a small proportion of all cases. While our research does not analyze substantiated reports of SEA, we include experiences and narratives of sexual misconduct that might never enter the UN's formalized system of reporting. Accordingly, this research captures a wider variety of sexual misconduct perpetrated in Haiti compared to counts of SEA formally reported and/or substantiated by the UN or TPCC. Consequently, a more community-driven and grounded understanding of personal, vicarious, and community-level experiences related to sexual relations with peacekeepers is possible.

In addition, within existing literature, SEA has been largely framed as a women's issue, as demonstrated through predominantly female-only samples. This analysis integrates the voices of Haitian men and women because Haitian males also shared narratives about MINUSTAH peacekeepers vis-à-vis the women and girls in their community. The results illustrate that Haitian men and boys are directly and indirectly affected by 
civilian-peacekeeper-perpetrated sexual misconduct, and their perspectives are important to establish a holistic understanding of how sexual relations with peacekeepers affect communities that host PO.

\section{Conclusions}

This research presented an exploratory analysis of the geographical distribution of narratives/experiences of peacekeeper-perpetrated sexual misconduct and the effect of sexual misconduct on the willingness to engage with the UN. Narratives of sexual misconduct perpetrated by MINUSTAH peacekeepers are positively associated with rural locations and positively associated with rejecting the UN/MINUSTAH. Given the secondary nature of this analysis and the convenience sampling employed, this quantitative analysis is an empirical steppingstone to understanding the distribution and consequences of peacekeeper perpetrated sexual misconduct. The UN's efforts to prevent and address SEA in Haiti could be strengthened by considering regions in Haiti where community members hold strong and negative views of SEA. The UN's allocation of policies/programs and building sustainable partnerships with national and regional Haitian sectors is one step toward rebuilding the UN's legacy of peacekeeping in Haiti.

Author Contributions: S.A.B., S.L. and S.E. conceptualized the original research idea and secured funding. S.E., S.A.B., and S.L. All contributed to data collection in Haiti. L.V. conducted the analysis with oversight by H.S. and S.A.B. L.V. drafted the original manuscript. S.E. assisted with the contextual interpretation. All authors reviewed the manuscript, provided critical feedback and approved the final submission. All authors have read and agreed to the published version of the manuscript.

Funding: This research was funded by the Arts and Humanities Research Council (grant\# AH/P008038/1), Principal Investigator Dr. Sabine Lee. Social Sciences and Humanities Research Council (grant \# 890-2016-0110; Canada Graduate Scholarship Masters), Principal Investigator Dr. Susan Bartels.

Institutional Review Board Statement: The study was conducted according to the guidelines of the Declaration of Helsinki, and approved by the University of Birmingham's Ethical Review Board (protocol ERN_16-0950) as well as by the Queen's University Health Sciences and Affiliated Teaching Hospitals Research Ethics Board (protocol \# 6020398).

Informed Consent Statement: After reviewing consent forms and information in Kreole and having an opportunity to ask questions, respondents indicated their willingness to participate by tapping a consent box on the tablet screen. Given the study was deemed to involve minimal risk, written consent was waived. The survey was implemented privately, and no identifying information was collected.

Data Availability Statement: The dataset(s) supporting the conclusions of this article is available in Figshare, [https:/ / figshare.com/s/896ed7d25a1fa1a4a09b] (accessed on 3 April 2020).

Acknowledgments: Firstly, we acknowledge the Haitians who participated in this study by sharing their experiences of living in proximity to peacekeeping bases. Our partners from Komisyon Fanm Viktim pou Viktim (KOFAVIV), the former Enstiti Travay Sosyal ak Syans Sosyal (ETS), and Bureau des Avocates Internationaux (BAI) were instrumental in implementing this research and conceptualizing the study design. We also acknowledge their expertise in shaping this study and interpreting the findings. In particular, we would like to acknowledge the research assistants from KOFAVIV and ETS who collected the data and participated in focus group discussions to interpret the present findings during field work conducted in 2019.

Conflicts of Interest: The authors declare no competing interests. The funders had no role in the design of the study; in the collection, analyses, or interpretation of data; in the writing of the manuscript, or in the decision to publish the results. 


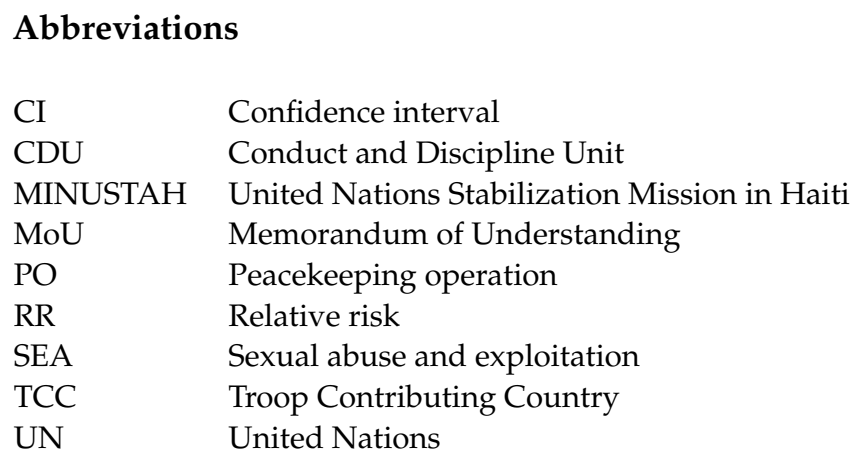

\section{Appendix A}

SenseMaker ${ }^{\circledR}$ cross-sectional survey

Prompting Questions:

1. Describe the best or worst experience of a particular woman or girl in your community who has interacted with foreign UN or MINUSTAH personnel. What happened?

2. Describe how living in a community with a UN or MINUSTAH presence has provided either a particular opportunity or a danger to a particular woman or girl in the community. What happened?

3. Describe the negative or positive experience of a particular women or girl who requested support or assistance after interacting with foreign UN or MINUSTAH personnel. What happened?

Triad Questions:

To answer the question, use your finger to drag the ball in each triangle to a position that best describes the experience shared in the story. The closer the ball to any one corner, the stronger that quality is in the context of the experience. If a triangle topic does not relate to your experience or you prefer to not answer the question, check the Not Applicable box by pressing on it with your finger.

1. This story is about: 1 . Financial/material security, 2. Social status, 3 . Emotional needs

2. In this story, the foreign UN or MINUSTAH personnel was: 1. In a position of authority, 2. Able to offer protection, 3 . Wealthy and able to provide support

3. Was the interaction in the story: 1. Friendly, 2. Business, 3. Relationship

4. In the story, what would a fair response look like? 1. Acceptance of responsibility, 2. Justice, 3. Reparation

5. In the story, it would have helped the woman or girl most to have had support from: 1 . The UN or MINUSTAH, 2. NGOs or civil society organizations, 3. Haitian authorities

6. In the story, barriers to the woman or girl getting a fair response were: 1 . Lack of information in the community about assistance, 2. Lack of response from Haitian authorities, 3 . Lack of response from the UN or MINUSTAH

7. In the story, what would have helped most to make the experience more positive: 1. Material/financial support, 2. Emotional support, 3. Legal support

8. Based on the events in the story, the presence of the UN or MINUSTAH led to: 1. Disrespect of Haitian values and laws, 2. Negative financial impact, 3. Anger and resentment

Multiple Choice Questions Pertaining to the Narrative:

(M1) Who is the story about?

About me

About someone in my household

About someone in my family who doesn't live in my household

About a friend

Community

Something I heard or read about

Prefer not to say 
(M2) How often does the situation in this story occur?

Very rarely

Occasionally

Regularly

Very frequently

All the time

Not sure

(M3) How important is it for others to hear and learn from your story

Must hear this story and take action

Should definitely hear this story and pay attention

Can learn some

(M4) Who would most benefit from hearing the story shared? (choose up to three)

Family

Friends

Neighbours

Haitian politicians

The UN or MINUSTAH

NGOs

The military of the foreigner

Churches

Community leaders

Business people

Girls in my community

Women in my community

Men in my community

Not sure

(M5) What is the emotional tone of this story?

Strongly positive

Positive

Neutral

Negative

Very negative

Not sure

(M6) How does your story make you feel (choose up to 3):

Angry

Disappointed

Embarrassed

Encouraged

Frustrated

Good

Happy

Hopeful

Indifferent

Relieved

Sad

Satisfied

Worried

Not sure

(M7) What country was the foreigner in the story from?

Uruguay

Sri Lanka

Pakistan 


Nepal
Argentina
Bolivia
Brazil
Chile
Peru
Indonesia
Jordan
Nigeria
Pakistan
Indonesia
Senegal
United States
France
Canada
Japan
China
Other
Don't know

(M8) What was the role of the foreigner with the UN or MINUSTAH?

Soldier (UNPOL, MINUSTAH, or Multinational Forces)

Civilian who works with the UN (doesn't wear a uniform)

Police

Worked for an NGO rather than the UN or MINUSTAH

Other

Don't know

Multiple Choice Questions Pertaining to the Participant:

(D1) What is your gender?

Female

Male

Prefer not to say

(D2) How old are you:

11-17 years old

18-24 years old

25-34 years old

35-44 years old

45-54 years old

$\geq 55$ years old

(D3) What is your marital status?

Married or living together as if married

Divorced/Separated from spouse

Widowed

Single, never married

Prefer not to say

(D4) What is your highest educational qualification?

No formal education

Some primary school

Completed primary school

Some secondary school

Completed secondary school

Some post-secondary school

Completed post-secondary school 
(D5) I'll read you a list of 5 items that some people have at home. Please tell me which of these you or your household owns. Your household consists of people who sleep under the same roof and eat the same meals. Chose as many as your family has:

radio

mobile phone

refrigerator or freezer

vehicle such as a truck, a car or a motorcycle

generator, inverter or a sun panel that provides electricity to your home.

None of the above

(D6) Here are some questions about your life

7 Strongly agree

6 Agree

5 Slightly agree

4 Neither agree nor disagree

3 Slightly disagree

2 Disagree

1 Strongly disagree

In most ways my life is close to my ideal.

The conditions of my life are excellent.

I am satisfied with my life.

So far I have gotten the important things I want in life.

If I could live my life over, I would change almost nothing

Multiple Choice Questions for the Research Assistant (not presented or answered by the participants)

(I1) Which category/group does this narrator belong to?

Child fathered by foreign UN or MINUSTAH personnel

Woman or girl who had interacted with foreign UN or MINUSTAH personnel

Family member of a woman or girl who had interacted with foreign UN or MINUSTAH personnel

Friend of a woman or girl who had interacted with foreign UN or MINUSTAH personnel

Community member where foreign UN or MINUSTAH personnel are hosted

Community leader where foreign UN or MINUSTAH personnel are hosted

Foreign UN or MINUSTAH personnel

Haitian UN or MINUSTAH personnel

Politician

NGO staff

Other

(I2) In what location was the interview conducted?

Citè Soleil

Charlie Log Base/Tabarre

Gonaives

St. Marc

Hinche

Leogane

Port Salut

Miragoane

Morne Casse/Fort Liberté

Cap Haitien

(I3) Do you think the participant was comfortable taking part in this survey? (choose up to three)

No-because of the survey

No-because of the topic 
No-because of the iPad

No-because of the voice recording

No-because of the SenseMaker questions

No-because of concerns about motivations or identity of the researchers

No-because of Voodoo related fears or concerns

No-other

Yes

Not sure

(I4) Was this story about a peace baby?

About peace baby

Mentioned a peace baby

About sexual abuse or exploitation by UN or MINUSTAH but not a peace baby

No

Not sure

(I5) Was this story about cholera?

About cholera

Mentioned cholera

About wrongdoings committed by foreign UN or MINUSTAH personnel but not about cholera

No

Not sure

(I6) Would you flag this story for translation and further analysis based on richness or interest?

Yes

No

Not sure

(I7) Which story number is this for this participant?

1 st,

2nd,

3rd,

4th

Appendix B. Bivariate Analysis of Covariates

Table A1. Bivariate Analyses Objective 1.

\begin{tabular}{cccc}
\hline Variable & $\begin{array}{c}\text { Exposure (Rural, } \\
\text { Urban, Semi-Urban) }\end{array}$ & $\begin{array}{c}\text { Outcome (Sexual } \\
\text { Misconduct) }\end{array}$ & $\begin{array}{c}\text { Anticipated Effect } \\
\text { on Model 1 }\end{array}$ \\
\hline Gender & $\begin{array}{c}\text { X2 }(15.2183,2) \\
p \text {-value }=0.0005\end{array}$ & $\begin{array}{c}\text { X2 }(4.3510,1) \\
\text {-value }=0.0370\end{array}$ & Potential Confounder \\
\hline Relationship Status & $\begin{array}{c}\text { X2 }(15.7667,2) \\
p \text {-value }=0.0004\end{array}$ & $\begin{array}{c}\text { X2 }(0.6553,1) \\
p \text {-value }=0.4182\end{array}$ & $\begin{array}{c}\text { Covariate that } \\
\text { predicts outcome }\end{array}$ \\
\hline \multirow{2}{*}{ Education } & X2 $(7.7058,6)$ & $\mathrm{X} 2=30.5128,3)$ & $\begin{array}{c}\text { Covariate that } \\
\text { predicts outcome }\end{array}$ \\
\hline Who was the & X2 $(37.1881,4)$ & X2 $(229.8993,2)$ & Potential Confounder \\
narrative about? & $p$-value $<0.0001$ & $p$-value $<0.0001$ & Potential Confounder \\
\hline \multirow{2}{*}{ Emotional Tone } & $\mathrm{X} 2(36.5457,4)$ & $\mathrm{X} 2(148.9354,2)$ & -value $<0.0001$ \\
\hline
\end{tabular}


Table A1. Cont.

\begin{tabular}{cccc}
\hline Variable & $\begin{array}{c}\text { Exposure (Rural, } \\
\text { Urban, Semi-Urban) }\end{array}$ & $\begin{array}{c}\text { Outcome (Sexual } \\
\text { Misconduct) }\end{array}$ & $\begin{array}{c}\text { Anticipated Effect } \\
\text { on Model 1 }\end{array}$ \\
\hline Income & $\begin{array}{c}\text { X2 }(46.8225,4) \\
p \text {-value }<0.0001\end{array}$ & $\begin{array}{c}\text { X2 }(14.3910,2) \\
p \text {-value }=0.0007\end{array}$ & Potential Confounder \\
\hline \multirow{2}{*}{ Age } & $\begin{array}{c}\text { X2 }(11.2858,4) \\
p \text {-value }=0.0235\end{array}$ & $\begin{array}{c}\text { X2 }(8.4806,2) \\
p \text {-value }=0.0144\end{array}$ & Potential Confounder \\
\hline
\end{tabular}

X2 = Chi Squared Statistic.

Table A2. Bivariate Analyses Objective 2.

\begin{tabular}{|c|c|c|c|}
\hline Variable & $\begin{array}{c}\text { Exposure (Narrative } \\
\text { Subject) }\end{array}$ & $\begin{array}{c}\text { Outcome (Reject } \\
\text { UN/MINUSTAH) }\end{array}$ & $\begin{array}{l}\text { Anticipated Effect } \\
\text { on Model } 2\end{array}$ \\
\hline Location & $\begin{array}{l}\mathrm{X} 2(257.4021,14) \\
p \text {-value }<0.0001\end{array}$ & $\begin{array}{c}\text { X2 }(48.3153,7) \\
p \text {-value }<0.0001\end{array}$ & Potential Confounder \\
\hline Gender & $\begin{array}{c}\mathrm{X} 2(8.2778,2) \\
p \text {-value }=0.0159\end{array}$ & $\begin{array}{c}\mathrm{X} 2(20.4978,1) \\
p \text {-value }<0.0001\end{array}$ & Potential Confounder \\
\hline Relationship Status & $\begin{array}{c}\mathrm{X} 2(1.5238,2) \\
p \text {-value }=0.4668\end{array}$ & $\begin{array}{c}\mathrm{X} 2(9.2698,1) \\
p \text {-value }=0.0023\end{array}$ & $\begin{array}{l}\text { Covariate that } \\
\text { predicts outcome }\end{array}$ \\
\hline Education & $\begin{array}{c}X 2(35.2458,6) \\
p \text {-value }<0.0001\end{array}$ & $\begin{array}{c}\mathrm{X} 2(5.0781,3) \\
p \text {-value }=0.1662\end{array}$ & $\begin{array}{l}\text { Covariate associated } \\
\text { with exposure }\end{array}$ \\
\hline $\begin{array}{c}\text { Who is this story } \\
\text { about? }\end{array}$ & $\begin{array}{l}X 2(308.0738,4) \\
p \text {-value }<0.0001\end{array}$ & $\begin{array}{l}\text { X2 }(101.5441,2) \\
p \text {-value }<0.0001\end{array}$ & Potential Confounder \\
\hline Emotional Tone & $\begin{array}{l}\mathrm{X} 2(1479.1143,4) \\
p \text {-value }<0.0001\end{array}$ & $\begin{array}{l}X 2(474.7267,2) \\
p \text {-value }<0.0001\end{array}$ & Potential Confounder \\
\hline Income & $\begin{array}{c}X 2(23.5081,4) \\
p \text {-value }=0.0001\end{array}$ & $\begin{array}{c}\mathrm{X} 2(0.2003,2) \\
p \text {-value }=0.9047\end{array}$ & $\begin{array}{l}\text { Covariate associated } \\
\text { with exposure }\end{array}$ \\
\hline Age & $\begin{array}{c}\text { X2 }(17.5705,4) \\
p \text {-value }=0.0015\end{array}$ & $\begin{array}{c}\mathrm{X} 2(7.9189,2) \\
p \text {-value }=0.0191\end{array}$ & Potential Confounder \\
\hline
\end{tabular}

X2 = Chi Squared Statistic.

\section{Appendix C. Sample Triad and Dyad Questions}

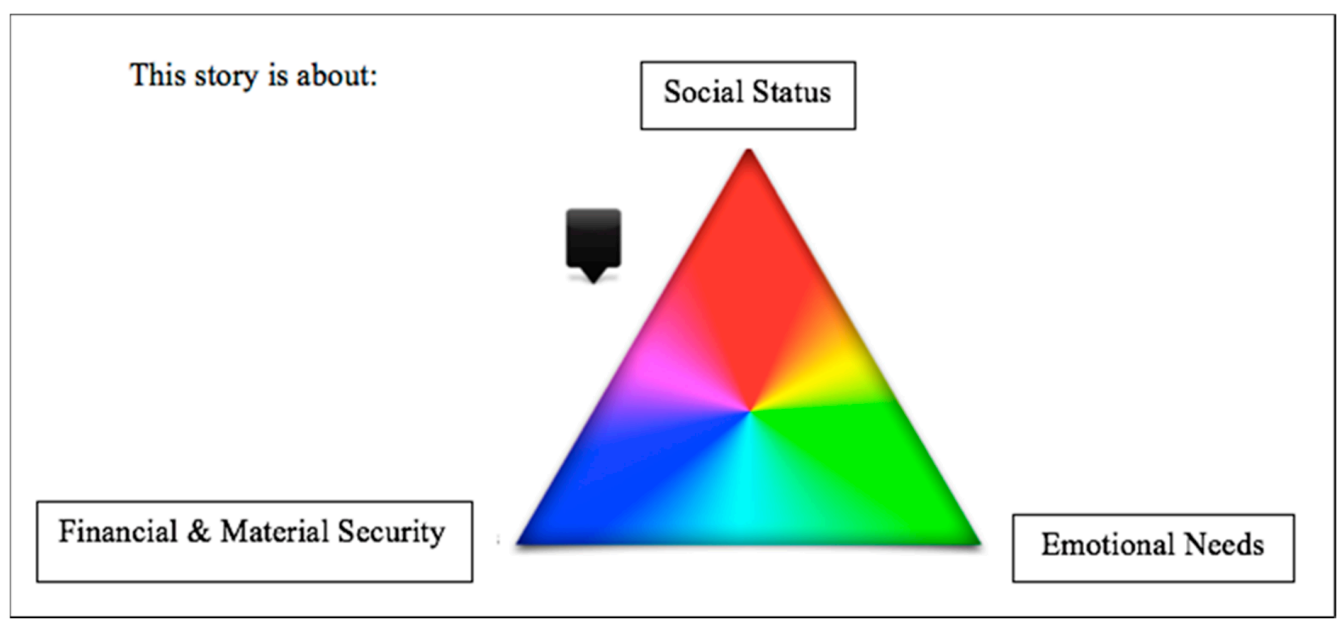

Figure A1. Example triad question. 
Events in the story led the community to have:

Overwhelming desire to engage with the UN/

Absolute Rejection of the

MINUSTAH UN/MINUSTAH

Figure A2. Example dyad question.

Appendix D

\section{Dyad Distribution}

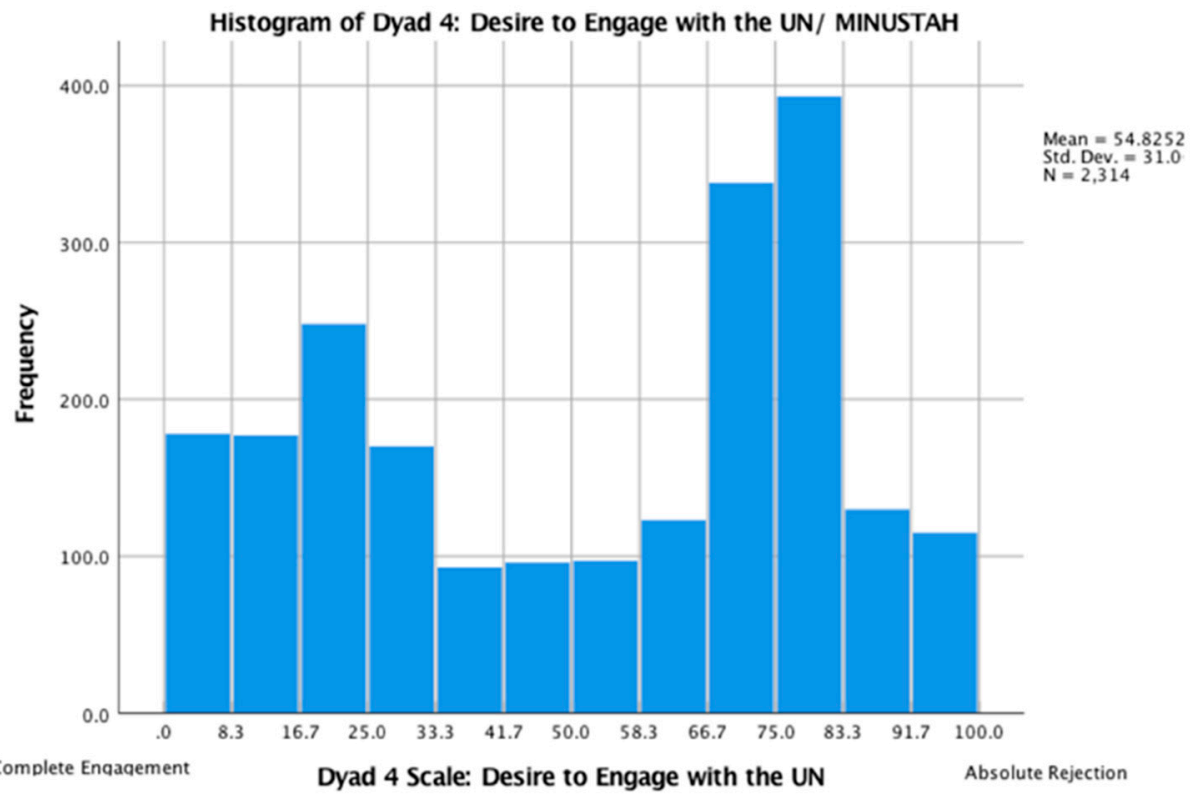

Figure A3. Distribution of Participant Responses to Dyad 4 (Desire to Engage with the UN/MINUSTAH). 


\section{Appendix E}

Table A3. Criteria used to classify narratives according to subject-type.

Exposure Level

Inclusion \& Exclusion Criteria

\section{Short Version:}

utral emotional tone AND not about UN/MINUSTAH

Narrative does not identify MINUSTAH peacekeepers as perpetuating wrongdoings such as the cholera outbreak and sexual misconduct. Narrative has a positive or neutral emotional tone and describes the following experiences or circumstances: employment opportunities offered by peacekeepers, perceptions of safely, peacekeeper public service \& providing

and neutral experiences with MINUSTAH peacekeeper $n=956$

\section{Short Version}

Sexual interactions between MINUSTAH peacekeepers and Haitian civilian rrespectivec

Detailed Version

Narrative mentions or describes sexual interactions or relations between Haitian women/girls and MINUSTAH peacekeepers. Examples of sexual interactions with peacekeepers include: sexual abuse, sexual exploitation, monogamous \& long-term relationships, children fathered by peacekeepers, sexual harassment, and sexual assault.

ual interactions with peacekeepers as well as narratives about the experiences of family/friends, community members, and ithin media stories are included.

ome narratives mention or discuss sexual interactions between MINUSTAH peacekeepers and Haitian men and boys; such narratives were also included in assault and sexual abuse.

\section{Example Excerpt from Narrative}

"My friend, to tell you the truth, when the MINUSTAH was in town, it was My friend, to tell you the truth, when the MIN USTAH was in town, it was friends. Some of them had my phone number and would even call me at to come to their house. They would give me a lot of things to take to my house. They used to give me a meal eat almost every Friday. I had some partners that when I go by, I would bring them, and they would get along with them too. (My men, this cholera business that you are talking about, I do not know about it because the MINUSTAH did not boil a pot of cholera) The MINUSTA did great things for me. You must recognize it when someone does a good thing for you. The MINUSTAH did great things for me. Yes indeed, the MINSUTAH did great things for me. They did such great thing for me that I cannot a find a [Narrator ID 1167]

Transactional sex
"Concerning the relationship between the ladies and the MINUSTAH, there is nothing free in life and no one would give you things or do you a favor withou expecting something in return. In term of the MINUSTAH, let's assume that the MINUSTAH offers a cell phone to a woman, but this guy did not find the buy the phone, so whether it is a man or a woman they'll be sext hilly harassed. The women who have kids by the MINUSTAH, it's their personal business with them and many times these women voluntarily take themselves to the base to join the soldiers. To me, I don't think there is anything wrong with that If two adults decide to get together, it is because there was mutual consent among them."

[Narrator ID 2260]

"It is possible that not all the MINUSTAH members are bad, but the ones that are not good among them should be removed. Because, the fact that they rape a young man in the area made them send all of them back instead of the one who did it. This young man was their friend. They use to give him money. He

Children

It was a Brazilian sy peacekeepers but my belly hadn't yet gotten bigger. He said he would help me with the child. Really, he left for his country and I wrote to him on facebook. I never received any news of him. He never responded. In terms of the child, in terms of school, he/she never went,... It's only me that's giving to the child to eat because I can't pay for school for the child... I need someone to help me send her/him to school, to have a future. [Narrator ID 409] 
Table A3. Cont.

Other Wrongdoings perpetrated by MINUSTAH peacekeepers and negative perceptions of MINUSTAH peacekeepers

\section{Short Version}

Serpetrated by MINUSTAH peacekeepers and other of the UN/MINUSTAH that have a negative motional tone.

The Micro-narrative mentions, describes, or references wrongdoings committed by MINUSTAH peacekeepers that are not related to sexual misconduct. Other wrongdoings include: peacekeepers responsible for choler outbreak, use of violence (tear gas, beating innocent civilians) as population control, contaminating water supplies, littering, kidnapping, stealing goats, motor-vehicle collisions, improper waste disposal, etc.

Unfavorable sentiments of the UN/MINUSTAH that have a negative emotion tone include micro-narratives about: colonialism, neo-colonialism, blaming Haiti's political situation on MINUSTAH, Haitian mobilization independen MINUSTAH, peacekeepers being financially compensated too much, etc.

\section{Example Excerpt from Narrative}

Negative perceptions of MINUSTAH unrelated to wrongdoing

Okay, look at how the Haitian people are dying of hunger, right now there is a big starvation in the country, people cannot eat, they cannot do anything. And then, and then the country pays MINUSTAH all that money as a salary, while the people are dying of hunger. Well, that MINUSTAH leave the country, all these money are spending in MINUSTAH, the Haitian people will be suspended to die or hunger, all thess Narrator ID 684]

Narrator ID 684]

It was a goat that was lost, now the goat was found. They found the goat in the orest. While it was walking now they take it kill it, eat it. After that they

would past the house in many cars. The children would call the MINUSTAH "my goat thief". I would tell them not to say that. I would beat them, they would insult me, sometimes, I would ignore them. But I never heard an adult speak badly of them. I have never heard where they say they were violent with person

Narrator ID 1337]

Peacekeepers responsible for the cholera outbreak

I am not a victim of cholera, but my relatives are victims. My father got it, $m y$ sister and my child as well. What I have been told about cholera is that

because they weren't were. They came with a powder that gives cholera,

everywhere. You understand? A powder that itch. They are the one who brought it here. So, we ask for justice. [Narrator ID 1818] 


\section{References}

Alexandra, Kylie. 2011. Peacekeepers' Privilege and Sexual Abuse in Post-Conflict Populations. Peace Review: A Journal for Social Justice 23: 369-76. [CrossRef]

Aning, Kwesi, and Fiifi Edu-Afful. 2013. Unintended Impacts and the Gendered Consequences of Peacekeeping Economies in Liberia. International Peacekeeping 20: 17-32. [CrossRef]

Baranyi, Stephen. 2011. Canada and the Travail of Partnership in Haiti. In Fixing Haiti: Minustah and Beyond. Edited by Jeorge Heine and Andrew Thompson. New York: United Nations University Press, pp. 205-28.

Barros, Aluísio J. D., and Vânia N. Hirakata. 2003. Alternatives for Logistic Regression in Cross-Sectional Studies: An Empirical Comparison of Models That Directly Estimate the Prevalence Ratio. BMC Medical Research Methodology 3: 1-13. [CrossRef] [PubMed]

Beber, Bernd, Michael J. Gilligan, Jenny Guardado, and Sabrina Karim. 2017. Peacekeeping, Compliance with International Norms, and Transactional Sex in Monrovia, Liberia. International Organization 71: 1-30. [CrossRef]

Catherine, Lutz, Gutmann Matthew, and Brown Keith. 2009. Conduct and Discipline in UN Peacekeeping Operations: Culture, Political Economy and Gender Report. Providene: Watson Institute for International Studies, Brown University.

Cognitive Edge. 2010. About Us: Cognitive Edge. Available online: http:/ / cognitive-edge.com/about-us/ (accessed on 21 June 2018).

Connors, Jane. 2019. A Victims' Rights Approach to the Prevention of, and Response to, Sexual Exploitation and Abuse by United Nations Personnel. Australian Journal of Human Rights 25: 498-510. [CrossRef]

Department of Health and Human Services. 2020. International Compilation of Human Research Protections. Available online: http:/ / www.hhs.gov / ohrp/international/ (accessed on 20 April 2020).

Diehl, Paul F. 2008. Peace Operations (War and Conflict in the Modern World), 1st ed. Cambridge: Polity Press.

dos Santos Parra, Mariana. 2019. Minustah's Legitimacy and the 'Security-First' Approach: Reassessing Statebuilding and Its Violent Features in the Case of Haiti. Journal of Intervention and Statebuilding 2977: 480-502. [CrossRef]

Edmond, Yanique M., Suzanne M. Randolph, and Guylaine L. Richard. 2007. The Lakou System: A Cultural, Ecological Analysis of Mothering in Rural Haiti. The Journal of Pan African Studies 2: 19-32.

Fawzi, M. C., W. Lambert, J. M. Singler, Y. Tanagho, F. Léandre, P. Nevil, D. Bertrand, M. S. Claude, J. Bertrand, M. Louissaint, and et al. 2005. Factors Associated with Forced Sex among Women Accessing Health Services in Rural Haiti: Implications for the Prevention of HIV Infection and Other Sexually Transmitted Diseases. Social Science and Medicine 60: 679-89. [CrossRef] [PubMed]

Girl Hub. 2014. Using Sensemaker ${ }^{\circledR}$ to Understand Girls' Lives: Lessons Learnt. Available online: http:/ / old.cognitive-edge.com/wpcontent/uploads/2015/04/GH-SenseMaker-brief.pdf (accessed on 20 April 2020).

Gordon, Grant M., and Lauren E. Young. 2017. Cooperation, Information, and Keeping the Peace: Civilian Engagement with Peacekeepers in Haiti. Journal of Peace Research 54: 64-79. [CrossRef]

Government of the Republic of Haiti. 2010. Action Plan for National Recovery and Development of Haiti: Immediate Key Initiatives for the Future. Available online: https:/ / www.recoveryplatform.org/assets/publication/Action_Plan_12April_haiti.pdf (accessed on 20 April 2020).

Heine, Jeorge, and Andrew Thompson. 2011. Introduction: Haiti's Governance Challenges and the International Community. In Fixing Haiti: Minustah and Beyond. Edited by Jeorge Heine and Andrew Thompson. New York: United Nations University Press, pp. 1-21.

Heinze, Georg, Christine Wallisch, and Daniela Dunkler. 2018. Variable Selection-A Review and Recommendations for the Practicing Statistician. Biometrical Journal 60: 431-49. [CrossRef]

Henry, Marsha. 2015. Parades, Parties and Pests: Contradictions of Everyday Life in Peacekeeping Economies. Journal of Intervention and Statebuilding 9: 372-90. [CrossRef]

Higate, Paul, and Marsha Henry. 2004. Engendering (in)Security in Peace Support Operations. Security Dialogue 35: 461-78. [CrossRef]

Institut Haïtien de l’Enfance. 2018. Haïti: Enquête Mortalité, Morbidité et Utilisation Des Services (EMMUS-VI) 2016-2017. Available online: https: / /www.dhsprogram.com/pubs/pdf/FR326/FR326.pdf (accessed on 1 May 2021).

Jennings, Kathleen M. 2008. Protecting Whom? Approaches to Sexual Axploitation and Abuse UN Peacekeeping Operations. Available online: http:/ / lastradainternational.org/lsidocs/fafo_approaches_abuse_0309.pdf (accessed on 20 April 2020).

Jennings, Kathleen M. 2014. Service, Sex, and Security: Gendered Peacekeeping Economies in Liberia and the Democratic Republic of the Congo. Security Dialogue 45: 313-30. [CrossRef]

Jennings, Kathleen M., and Morten Bøås. 2015. Transactions and Interactions: Everyday Life in the Peacekeeping Economy. Journal of Intervention and Statebuilding 9: 281-95. [CrossRef]

Jennings, Kathleen M., and Vesna Nikolić-Ristanović. 2009. UN Peacekeeping Economies and Local Sex Industries: Connections and Implications. MICROCON Research Working Paper 17. Brighton: Institute of Development Studies at the University of Sussex. [CrossRef]

Karim, Sabrina, and Kyle Beardsley. 2013. Female Peacekeepers and Gender Balancing: Token Gestures or Informed Policymaking? International Interactions 39: 461-88. [CrossRef]

Karim, Sabrina, and Kyle Beardsley. 2016. Explaining Sexual Exploitation and Abuse in Peacekeeping Missions: The Role of Female Peacekeepers and Gender Equality in Contributing Countries. Journal of Peace Research 53: 100-115. [CrossRef] 
Karim, Sabrina. 2017. Reevaluating Peacekeeping Effectiveness: Does Gender Neutrality Inhibit Progress? International Interactions 43: 822-47. [CrossRef]

Lee, Sabine, and Susan Bartels. 2020. 'They Put a Few Coins in Your Hand to Drop a Baby in You': A Study of Peacekeeper-Fathered Children in Haiti. International Peacekeeping 27: 177-209. [CrossRef]

Luo, Ji, Jiajia Zhang, and Han Sun. 2014. Estimation of Relative Risk Using a Log-Binomial Model with Constraints. Computational Statistics 29: 981-1003. [CrossRef]

Ministère de la Santé Publique. 2020. Politique Nationale de Recherche En Santé PUBLIQUE ET DE LA POPULATION. Available online: https:/ / mspp.gouv.ht/site/downloads/PolitiqueNationaledeRechercheenSante-MSPP21janvier2020VF.pdf (accessed on 20 April 2020).

Moncrief, Stephen. 2017. Military Socialization, Disciplinary Culture, and Sexual Violence in UN Peacekeeping Operations. Journal of Peace Research 54: 715-30. [CrossRef]

Morris, Claire. 2010. Peacekeeping and the Sexual Exploitation of Women and Girls in Post-Conflict Societies: A Serious Enigma to Establishing the Rule of Law. Journal of International Peacekeeping 14: 184-212. [CrossRef]

Neudorfer, Kelly. 2014. Reducing Sexual Exploitation and Abuse: Does Deterrence Work to Prevent SEAs in UN Peacekeeping Missions? International Peacekeeping 21: 623-41. [CrossRef]

Nordås, Ragnhild, and Siri C. A. Rustad. 2013. Sexual Exploitation and Abuse by Peacekeepers: Understanding Variation. International Interactions 39: 511-34. [CrossRef]

Orozco, Manuel. 2006. Understanding the Remittance Economy in Haiti. Methodology. Available online: http:/ / archive.thedialogue. org/PublicationFiles/Understanding\%20the\%20remittance\%20economy\%20in\%20Haiti.pdf (accessed on 20 April 2020).

Padgett, Andrew, and Tonia Warnecke. 2011. Diamonds in the Rubble: The Women of Haiti. Journal of Economic Issues 45: 527-58. [CrossRef]

Porter, Catherine, Michael Crowley, and Constant Meheut. 2021. Haiti's President Assassinated in Nighttime Raid, Shaking a Fragile Nation. New York Times. July 7. Available online: https://www.nytimes.com/2021/07/07/world/americas/haiti-presidentassassinated-killed.html?action=click\&module=Top\%20Sto-ries\&pgtype=Homepage (accessed on 20 April 2020).

Rivera, Juan. 2018. The Impact of Organized Crime on Peace Support Operations. In Law Enforcement within the Framework of PSO. Oxford: Martinus Nijhoff Publishers, pp. 75-104. [CrossRef]

Romulus, Célia. 2016. Haiti: A Sociopolitical Timeline (1980-2014). In Witness to History_Témoin de l'Histoire-Thony Bélizaire. Edited by Raoul Peck. New York: Velvet Film.

Simić, Olivera, and Melanie OBrien '. 2014. 'Peacekeeper Babies': An Unintended Legacy of United Nations Peace Support Operations. International Peacekeeping 21: 345-63. [CrossRef]

Simić, Olivera. 2009. Rethinking 'sexual Exploitation' in UN Peacekeeping Operations. Women's Studies International Forum 32: $288-95$. [CrossRef]

Spangaro, Jo, Chinelo Adogu, Geetha Ranmuthugala, Gawaine Powell Davies, Léa Steinacker, and Anthony Zwi. 2013. What Evidence Exists for Initiatives to Reduce Risk and Incidence of Sexual Violence in Armed Conflict and Other Humanitarian Crises? A Systematic Review. PLoS ONE 8: e62600. [CrossRef]

Talentino, Andrea. 2007. Perceptions of Peacebuilding: The Dynamic of Imposer and Imposed Upon. International Studies Perspectives 8: 152-71. [CrossRef]

United Nations Secretariat. 2003. Special Measures for Protection from Sexual Exploitation and Sexual Abuse. Available online: https://www.un.org/en/ga/search/view_doc.asp?symbol=ST/SGB/2003/13 (accessed on 20 April 2020).

United Nations Secretariat. 2005. A Comprehensive Stragety to Eliminate Future Exploitation and Abuse in United Nations Peacekeping Operations. United Nations: Geneva, Switzerland, vol. 24790.

United Nations Security Council. Resolution 1908 (2010). New York, 2010a. Available online: https://daccess-ods.un.org/TMP/5441 516.63780212.html (accessed on 20 April 2020).

United Nations Security Council. 2010b. Resolution 1927 (2010). New York. Available online: https://undocs.org/S/RES/1927 (accessed on 20 April 2020).

United Nations. 2019. 2017 and 2018 Report: Trust Fund in Support of Victims of Sexual Exploitation and Abuse. Available online: https:/ / conduct.unmissions.org/remedial-trust-fund (accessed on 20 April 2020).

United Nations. 2020a. Conduct in UN Peace Missions: Sexual Exploitation and Abuse. Available online: https://conduct.unmissions. org/sea-overview (accessed on 21 March 2020).

United Nations. 2020b. Sexual Exploitation and AbuseConduct in UN Field Missions. Available online: https:/ / conduct.unmissions. org/sea-victims (accessed on 21 March 2020).

Vahedi, Luissa, Susan A. Bartels, and Sabine Lee. 2019. 'Even Peacekeepers Expect Something in Return': A Qualitative Analysis of Sexual Interactions between UN Peacekeepers and Female Haitians. Global Public Health 1692: 1-14. [CrossRef]

Vahedi, Luissa, Susan Bartels, and Sabine Lee. 2020. 'His Future Will Not Be Bright': A Qualitative Analysis of Mothers' Lived Experiences Raising Peacekeeper-Fathered Children in Haiti. Children and Youth Services Review 119: 105625. [CrossRef]

Vahedi, Luissa, Heather Stuart, Stéphanie Etienne, Sabine Lee, and Susan A. Bartels. 2021. Gender-Stratified Analysis of Haitian Perceptions Related to Sexual Abuse and Exploitation Perpetrated by UN Peacekeepers during MINUSTAH. Sexes 2: 216-43. [CrossRef]

VanderWeele, Tyler J. 2019. Principles of Confounder Selection. European Journal of Epidemiology 34: 211-19. [CrossRef] [PubMed] 
Verner, Dorte. 2008. Making Poor Haitians Count Poverty in Rural and Urban Haiti Based on the First Household Survey for Haiti. World. Available online: https:/ / openknowledge.worldbank.org/handle/10986/6555 (accessed on 20 April 2020).

Weir, Kirsten. 2019. Studying Adolescents without Parents' Consent: A New APA Resolution Supports Mature Minors' Participation in Research without Parental Permission. Washington, DC: American Psychological Association, Available online: https://www.apa.org/ monitor/2019/02/parents-consent (accessed on 20 April 2020). 